\title{
Voting Counts: Participation in the Measurement of Democracy*
}

\section{Bruce E. Moon, Jennifer Harvey Birdsall, Sylvia Ciesluk, Lauren M. Garlett, Joshua J. Hermias, Elizabeth Mendenhall, Patrick D. Schmid, and Wai Hong Wong}

The measures of democracy commonly used in empirical research suffer notable limitations, primarily the exclusion of participation. As a result, quantitative studies may undervalue the effect of democracy on important social outcomes or misinterpret the aspect of democracy responsible for that effect. We respond by introducing and validating two variants of a new indicator, the Participation Enhanced Polity Score (PEPS), which augments institutional factors with the breadth of citizen par-

Bruce E. Moon is professor of international relations at Lehigh University in Bethlehem, Pennsylvania. He is the author of The Political Economy of Basic Human Needs (Cornell University Press, 1991) and two editions of The Dilemmas of International Trade (Westview Press, 1996, 2000).

Jennifer Harvey Birdsall is a researcher for a NGO in Geneva, Switzerland. She received her B.A. in international relations and economics from Lehigh University and her M.S. in global affairs from Rutgers University-Newark.

Sylvia Ciesluk is pursuing an M.A. at the Fletcher School at Tufts University. She received her B.S. in economics from Lehigh University.

Lauren M. Garlett is a geography teacher at Bellamy Middle School in Chicopee, Massachusetts. She received both her B.A in international relations and her M.Ed. in secondary education from Lehigh University.

Joshua J. Hermias is associate director of the Global Young Leaders Conference in Washington, D.C. He received his B.A. in economics from Lehigh University and his M.A. in international development from the University of East Anglia, Norwich, England.

Elizabeth Mendenhall is pursuing a Masters in International Affairs (MIA) in economic and political development at Columbia University. She received a B.A. in international relations at Lehigh University.

Patrick D. Schmid is a Ph.D. candidate in computer science at Lehigh University. He received both his B.S. and M.S. in computer science from Lehigh University.

Wai Hong Wong is a research associate at FactSet Research Systems. He received his B.A. in international relations and economics at Lehigh University.

Studies in Comparative International Development, Summer 2006, Vol. 41, No. 2, pp. 3-32. 
ticipation. We demonstrate, using statistical evidence on democratic persistence, basic needs fulfillment, and gender equality, that no measure of democracy can be considered an accurate representation of its basic character without directly including participation as a core component.

\section{Introduction}

$\mathrm{D}$ emocracy earns wide praise for both philosophical and practical reasons. Theorists and activists alike extol it as an environment in which individuals can realize their capabilities. Researchers emphasize its implications for peace, prosperity, and equality. However, such claims are only as strong as the empirical methods that produce these findings. Those methods, in turn, must rest upon a sound definition and measurement strategy that effectively captures the key features of democracy.

Measures used in previous studies suffer notable limitations. In particular, democracy indicators such as Polity and Freedom House, which emphasize institutional arrangements and civil liberties, neglect citizen participation (Jaggers and Gurr, 1995; Freedom House, 2002). For example, some countries are coded in the Polity dataset as "pure" democracies despite yawning gaps in participation, notably the United States during slavery and Switzerland before women's suffrage. The omission of an adequate measure of participation undermines the practical basis for claims of democratic superiority and may distort the empirical relationship of democracy and its postulated outcomes.

We correct this oversight by creating two variants of a new indicator of nations' democracy levels, the Participation Enhanced Polity Score (PEPS). The PEPS variants combine institutional factors with considerations of the breadth of citizen participation. By validating these new indicators, we demonstrate the necessity of including participation in any robust measure of democracy. Section two reviews the range of definitions and measures previously offered for democracy. Section three demonstrates the intuitive validity of our concept of participatory democracy by contrasting actual political participation with institutional characteristics and suffrage limitations. In section four, we detail our PEPS measures and lay out our validation plan to demonstrate that they better fit theoretical expectations than existing democracy measures. In sections five, six, and seven, we replicate studies linking democracy with: (1) a variable said to cause democracy (economic development), (2) one that is internal to the democratic process (the persistence and durability of institutions), and (3) two important consequences of democracy (the attainment of basic human needs and gender equality). These replicated studies demonstrate not only that our new measure is as useful as the existing ones, but also, in important respects, it is an improvement.

\section{On Measuring Democracy}

Both ancient and modern political philosophers have struggled to describe the democratic "ideal," a governance system in which every citizen participates in the political process that shapes society's fate and, through it, his or her own. Whatever the problems of capturing such an ideal, the classification of actual states is more prob- 
lematic. In The Politics, Aristotle (1996: 120) writes that a form of government "is a question of degree; an oligarchy, for example, may become more or less oligarchical, and a democracy more or less democratic." More recently, Seymour Martin Lipset (1959: 73) observed "democracy is not a quality of a social system which either does or does not exist, but rather a complex of characteristics which may be ranked in many different ways." Researchers have operationalized "democracy" by various means, each reflecting a unique view of what lies at the core of the "ideal democracy."1

In a review of nine projects gathering data on democracy, Gerardo L. Munck and Jay Verkuilen (2002a: 9) warn against "maximalist" or "minimalist" definitions that include either too many or too few theoretically relevant attributes. ${ }^{2}$ Maximalist definitions, as exemplified by Freedom House's (2000) freedom index, "tend to be so overburdened as to be of little analytical use," composed more of lists of characteristics than a tightly defined essence. Freedom House classifies nations as free, partly free, and not free on scales encompassing 25 conceptions of political rights and civil liberties. Because some of these attributes - such as "socioeconomic rights," "property rights," and "freedom from war"- are certainly not exclusive to democracy, we do not consider them explicit democracy scales, even though empirical researchers often use them under the implicit assumption that "free" states are more democratic (Starr, 1991, 1999; Lipset, Seong, and Torres, 1993; Burkhardt and LewisBeck, 1994).

At the other extreme lies the Polity Project (Jaggers and Gurr, 1995), which has produced the most widely used democracy measure. Its intellectual genesis can be traced to Harry Eckstein and Ted R. Gurr (1975), who defined the character of a political regime principally in terms of its authority relations. ${ }^{3}$ Keith Jaggers and Gurr (1995: 471) clarify the conceptual basis of their measurement approach as:

At its theoretical core, we argue that there are three essential, interdependent elements of democracy as it is conceived of in Western liberal philosophy. The first is the presence of institutions and procedures through which citizens can express effective preferences about alternative political policies and leaders. . . . A second component of Western-conceived democracy is the existence of institutionalized constraints on the exercise of executive power. The third dimension of democracy ... is the guarantee of civil liberties to all citizens in their daily lives and in acts of political participation.

Polity is an excellent measure in many respects and we have incorporated it into our own operationalization of democracy. Polity combines annual democracy and autocracy indicators to create an overall score ranging from -10 (pure autocracy) to +10 (pure democracy). Its broad coverage, together with open availability and explanatory definitions, makes the various Polity data sets, most recently version IV, popular among large-N researchers. ${ }^{4}$ Still, Polity exemplifies the concern of Munck and Verkuilen (2002a) that a minimalist measurement approach might omit an attribute necessary to a full definition. Robert A. Dahl's (1971) iconic formulation specifies that a democracy must meet the conditions of "contestation" and "inclusiveness" (near-universal participation in that contestation). Polity effectively captures the competitiveness of elections and limitations on executive power, but is less successful in tapping the participation dimension. 
On the contrary, Monty G. Marshall et al. (2002) contend that Polity incorporates participation. They correctly point out that the measure encompasses suffrage through its inclusion of the "competitiveness of political participation." Both Munck and Verkuilen (2002b) and Pamela Paxton (2000) note, and we agree, that this approach falls short. It adopts a low and arbitrary threshold to identify restricted participation: 20 percent of the adult male population. ${ }^{5}$ As we will show below, this methodology allows exclusionary regimes to attain very high democracy scores. ${ }^{6}$

\section{Democracy and Participation}

The extension of suffrage to all adults, male and female, is an undeniably critical feature of democratization. Revision of Polity and similar measures is necessary on these grounds alone. Our critique goes further. We argue, in the "civic republican" tradition, that it is profoundly misleading to characterize a political system as strongly democratic without broad (if not universal) genuine participation, especially in the electoral process where those who are governed provide approbation to those who govern. It is not enough that citizens have a right to participate. To make democracy meaningful and different from other governance systems, citizens must actively exercise that right.

Part of democracy's normative appeal is its promise to maximize the interests of the citizenry and further its collective values. But it will do so only if citizens use participation to convey their influence. As V.O. Key (1949: 527) puts it, "The blunt truth is that officials are under no compulsion to pay much heed to classes and groups of citizens that do not vote." It is not just that higher rates of participation make government responsive to a larger share of the population, even though that itself makes a system more democratic. As Stephen J. Rosenstone and John Mark Hansen (1993: 241) remind us, "When many citizens turn out to vote, they are more representative of the citizenry than when fewer people vote." Arend Lipjhart (1997) extensively documents that low participation rates invariably change the class and ethnic composition of the electorate.

Ballot box power aside, extensive participation transforms the character of the political system. It is particularly crucial in shaping the collective identity underlying democracy's most cherished consequence, achieving social justice and egalitarian outcomes across class, gender, and ethnic cleavages. Democracy's intrinsic value extends beyond its effect on policy. Democratic participation not only enhances the moral legitimacy of the public will, but also allows for the "self-actualization" of its citizens (Finkel, 1985). It is an extension of the individual's human capabilities of freedom, autonomy, and political agency, an element of what Amartya Sen (1999) says "what one can do or be." Yet democracy can empower the individual and sustain the community only if its processes incorporate the participation of all of those affected by it (Parry, Moyser, and Day, 1992). ${ }^{8}$

Some researchers have responded by emphasizing universal suffrage as central to democracy. From the participatory perspective, it is hardly a sufficient criterion for achieving the democratic ideal because participation may be quite narrow wherever citizens have the legal right to vote. ${ }^{9}$ Nonetheless, three examples corresponding to the most common means of suffrage denial illustrate that universal suffrage is a necessary condition for democracy. Polity's coarse-grained measure misrepre- 
sents the level of democracy in each of these polities by neglecting to reflect adequately its limited degree of participation. Class exclusion (on the basis of property) is represented most clearly by the evolution of participation in Great Britain. Ethnic exclusion is demonstrated most vividly by the role of race in South Africa. Switzerland illustrates both gender exclusion and the broader point that participation levels may reveal previously indiscernible aspects of a system's institutional structure.

Figure 1 illustrates Britain's political evolution, which has informed much of the literature on the theoretical "requisites" of democracy (Lipset, 1959), and underscores the limitation of Polity's treatment of political participation. Polity's 21-point democracy/autocracy scale, illustrated by the dashed line, tracks the major changes in British political history, but only roughly. The Reform Bill of 1832 revised a complicated system of determining the franchise by increasing the number of voters from 500,000 to 813,000. Despite this modest expansion, changes in the Polity Score for Britain give a sense of greatly expanded democracy, moving from a -2 $($ democracy $=4$, autocracy $=6)$ to $a+3($ democracy $=6$, autocracy $=3)$. However, as illustrated by the dotted line, only six percent of the adult population voted even after the reform. ${ }^{10}$ While the male franchise broadened considerably by 1884 , "suffrage still excluded agricultural workers ... [and] servants" (Palmer and Colton, 1992: 610). Actual voter turnout reached 12 percent of the population only in the election of 1885 before falling thereafter, and it did not return to that level again until 1918.

All the while, Polity scores for executive recruitment and competition increased while institutionalized autocracy decreased. In 1880, the Polity democracy score

Figure 1

Democracy in the United Kingdom

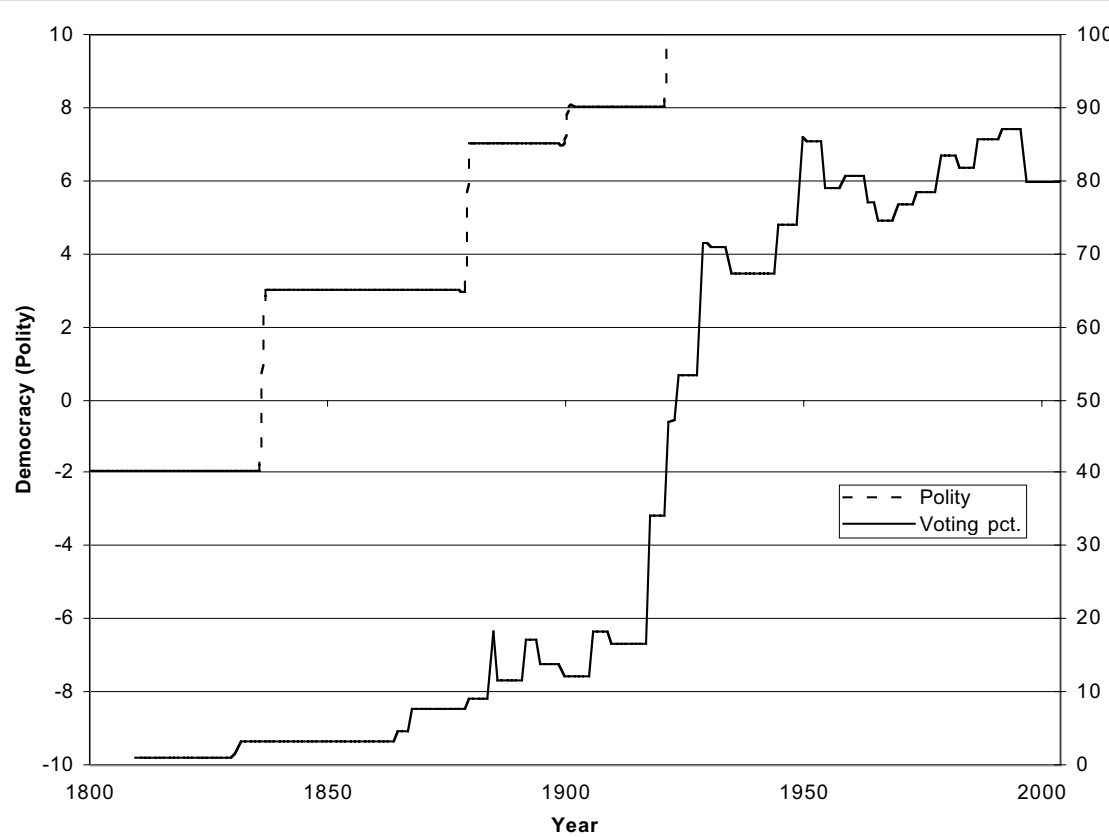


stood at 7 (autocracy $=0$ ). By 1901, the democracy score rose to 8 and, by 1922 , Polity suggests Britain was a "perfect 10" democracy, even though full male suffrage was not achieved until 1918 and full female suffrage until 1928. Britain has received the highest democracy rating since, although the voting rate has never exceeded 60 percent of the adult population. The high scores that Britain receives from 1880 on are misleading and, with respect to changes in participation, mistimed. As Figure 1 illustrates, participation doubled during a period Polity records as unchanged and doubled again during a modest two-point move in Polity.

The racial exclusion in South Africa also demonstrates the danger of conceiving democracy without taking account of the breadth of citizen participation. According to Polity, South Africa was a relatively stable democracy from 1910 until 1989 scoring a +4 (democracy $=7$, autocracy $=3)$. A positive score is surprising because it ignores the exclusion of the 90 percent of the population that did not - most could not-vote. While democracy existed in white South Africa, from the viewpoint of breadth of participation, the democracy measure is misleading. In particular, one would hardly expect a political system marked by such rights infringements and participation restrictions to produce the outcomes usually associated with democracy, especially in attaining basic needs or other dimensions of broad social development.

Switzerland, our final example, has scored a perfect +10 in the Polity dataset since 1848, even though women - roughly half the population-were not granted the right to vote until 1971, 123 years later. Furthermore, electoral turnout has hovered around 30 percent recently, despite virtually universal suffrage. One reason for this might be that Switzerland's collective executive is an organizational form that diminishes voter motivation by minimizing the significance of election outcomes. ${ }^{11}$ Surely such a system should be regarded as less democratic than one in which most citizens participate in elections and actually make a difference in leadership and policies.

The failure of Polity to record this limitation on democracy is not at all unique to Switzerland, and Polity's treatment of gender restrictions is mirrored by other measures. Paxton notes $(2000: 104)$ that "we should recognize that our current efforts at assessing explanations are focused on a restrictive form of democratization." She further observes that if the dates when many countries transitioned to democracy were adjusted to reflect accurately when the whole voting age population was granted suffrage, many early examples of democracy would take on a very different appearance. Even the "waves of democratization" identified by Huntington (1991) would be shown to be mistimed.

In response, Kenneth A. Bollen and Paxton (2003) have greatly advanced on Polity's approach by developing a new dataset that explicitly codes actual legal restrictions on the franchise. They compute a precise index of the extent of legal suffrage grading countries on a scale from zero to 100 percent (universal suffrage). Their choice of how to code such restrictions is reasonable, though inevitably subjective, and the resulting index will allow studies of suffrage not previously possible. ${ }^{12}$

The major flaw in relying upon the official franchise is suggested by the observation that in the 1990s all but a handful of countries were coded as having suffrage at 98 percent or more, while actual voting rates were far lower and varied quite widely. One reason is that the absence of legal proscriptions does not preclude re- 
strictive, but more difficult to quantify, institutional barriers. Many factors prevent voting, make it difficult, or exact excessive costs for participation in marginal democracies. These include political violence, societal pressures, intimidation, procedural irregularities, illiteracy, language and educational limitations, the absence of transportation, and party boycotts. Even in relatively well-institutionalized political systems, the ease of participation varies considerably. ${ }^{13}$ A regression analysis lends credibility to our caution by revealing that Bollen and Paxton's indicator of formal suffrage limitations explains less than 10 percent of the variance in the percentage of the adult population casting ballots. ${ }^{14}$ To assume that formal statutory suffrage limitations accurately measure the myriad of real participation restrictions invites large measurement error.

Accordingly, to measure the breadth of political participation, we prefer an approach based on actual voting records. In the process, we lose the ability to distinguish between informal restrictions and citizen choice as the explanation for low turnouts, but this distinction is far from clear-cut and almost impossible to measure. Moreover, since we regard participation itself as the core of the matter, the explanation for turnout rates is not central to identifying democracy levels. We admit it is tempting to label some reasons for nonparticipation a strength of the political system ("I am so confident that officials will decide wisely, I do not need to vote.") and others a weakness ("I don't vote because the available candidates are all equally unlikely to represent me."). Even if we could identify the attitudes underlying voter apathy, it would be irrelevant to judging whether a political system is participatory and, therefore, democratic.

One potential influence on turnout levels merits special mention, the potentially distorting effect of compulsory voting laws. The cases that introduce the greatest distortions are those notorious autocracies that statutorily mandate voting and subsequently report nearly 100 percent turnout. However, they do not affect our analysis since the participation rate of one-party states is coded as missing data in our principal data source, IDEA (2003). For the vast majority of nations, compulsory voting legislation is so lightly enforced and prescribes such small sanctions - mostly relatively modest fines - that it is more accurately considered an incentive to participate than a requirement to do so. ${ }^{15}$ Citizens must weigh many incentives and disincentives for voting, including peer pressure, a desire to influence policy and choose leaders, a sense of obligation, the hope of economic benefits from some candidates, the opportunity costs of voting, and many others we cannot identify or measure. As we are not comfortable in judging which of these incentives and disincentives pass muster as democratic in spirit, those states with compulsory voting have not been disqualified as democracies.

Our decision in this matter was reinforced by an analysis leading us to doubt that compulsory voting statutes have enough impact on turnout to warrant singling them out among the other determinants of participation. To test this effect, we used IDEA data (Pintor and Gratschew, 2002) to construct dummy variables for nations with compulsory voting legislation. IDEA identified four categories of such nations, according to the level of enforcement. In 2003, 31 of the 159 nations in our sample had some compulsory voting legislation, with nine coded as having strong enforcement and another 10 with weak enforcement. ${ }^{16}$

The initial analysis found nations with compulsory voting had turnout rates about 
Table 1

OLS Regression of Turnout on Compulsory Voting

\begin{tabular}{lcccc}
\hline & Coefficient & Std Error & $\boldsymbol{t}$ & $\boldsymbol{P}>|\boldsymbol{t}|$ \\
\hline Strong Enforcement & -.011 & .064 & -0.18 & 0.537 \\
Weak Enforcement & .110 & .061 & 1.81 & 0.112 \\
No Enforcement & -.002 & .072 & -0.03 & 0.752 \\
Enforcement n/a & -.113 & .084 & -1.34 & 0.441 \\
Constant & .665 & .016 & 40.63 & 0.000 \\
\hline
\end{tabular}

$\mathbf{r}^{2}=0.034$ adjusted $\mathbf{r}^{2}=.001$ probability of $\mathbf{F}=0.25 \mathrm{~N}=159$

1.3 percentage points higher than those that did not, but the effect was not statistically significant. Further analysis, reported in Table 1, shows nations with strongly enforced compulsory voting had an average of 1.1 percent lower voting rates, whereas nations with weak enforcement averaged nearly 11 percent higher rates, though neither effect was statistically significant.

This pattern supports Aníbal Pérez-Liñán's (2001) contention that the effect of compulsory voting laws are due more to "the sense of duty" they create than to any real coercion. Thus, they fall within the category of mobilization strategies that vary widely across nations so that those nations using them do not warrant exclusion. ${ }^{17}$ We conclude the effect of compulsory voting, if present at all, is not large enough to threaten the validity and reliability of voting-based measures. Buoyed by these findings, we create a new measure retaining the strengths of Polity's "institutionalized democracy," but augmenting what we see as its significant weakness, the omission of a sensitive participation component.

\section{The Participation Enhanced Polity Scores}

In response to the failure of extant measures to encompass adequately participation, we propose two variants of a new measure of participatory democracy, which we call PEPS1 and PEPS2. Both combine Polity's institutionalized authority relations with a behavioral dimension, the percentage of the adult population participating in the electoral process. ${ }^{18}$ We begin by defining a voter turnout scalar (VTS), such that at year $t$ for country $i$ :

$$
\text { VTS }_{i, t}=\text { Votes }_{i, t} / \text { Adult Population }_{i, t}
$$

Our analysis is based principally on the 1950-2003 period, for which our data source was IDEA (2003) and reports both votes and the adult population. ${ }^{19}$ IDEA includes only those elections in which "there was a degree of competitiveness. . . . This criterion excludes one-party states. ..." We code any case in which no votes are recorded by IDEA as missing data. In the few analyses we conducted for the period before 1950, we used Tatu Vanhanen (2000) as the data source. ${ }^{20}$

PEPS1 is a simple modification of Polity's 21-point democracy score. It is based upon the principle that institutionalized authority relations and citizens' electoral participation each give expression and meaning to the other. Participation is trivial if it does not influence policies through institutions that transmit the popular will. 
Authority relations that seemingly convey power to the electorate are not very meaningful if the electorate is not itself a sizable fraction of the citizenry. To compute PEPS1, we first multiply the VTS for each state by the Polity IV democracy score. This reduces the democracy score proportionally as voting turnout falls below 100 percent of the adult population. Then, emulating the 21-point Polity scale, we subtract the Polity autocracy variable from this adjusted democracy score to yield a continuous measure of participatory democracy:

$$
\text { PEPS }_{i, t}=\left(\operatorname{VTS}_{i, t} * \text { Polity Democracy Score } \text { S }_{i, t} \text { - Polity Autocracy Score } \text { S }_{i, t}\right.
$$

This measure recognizes much finer distinctions predicated on levels of participation, as illustrated by Figure 2, where the line signifying PEPS1 properly records the considerable expansion in the breadth of participatory democracy experienced by the United States since Polity first judged it a "perfect 10" in the slave-holding era of 1845. PEPS 1 can also differentiate among the 35 countries coded as 10 by Polity in 2003, recognizing several European countries just a fraction below 10 as well as Costa Rica (about 6), the United States (about 5), and Switzerland (around 4). ${ }^{21}$ Following Zachary Elkins (2000), PEPS1 may be justified on levels-of-measurement grounds, if the additional information contained in the continuous measure improves upon predictions derived from the categorical one, a test we perform below.

This multiplicative construction ensures that the participation rate carries no weight when the Polity democracy score is zero and has little impact on the overall

Figure 2

Democracy in the United States

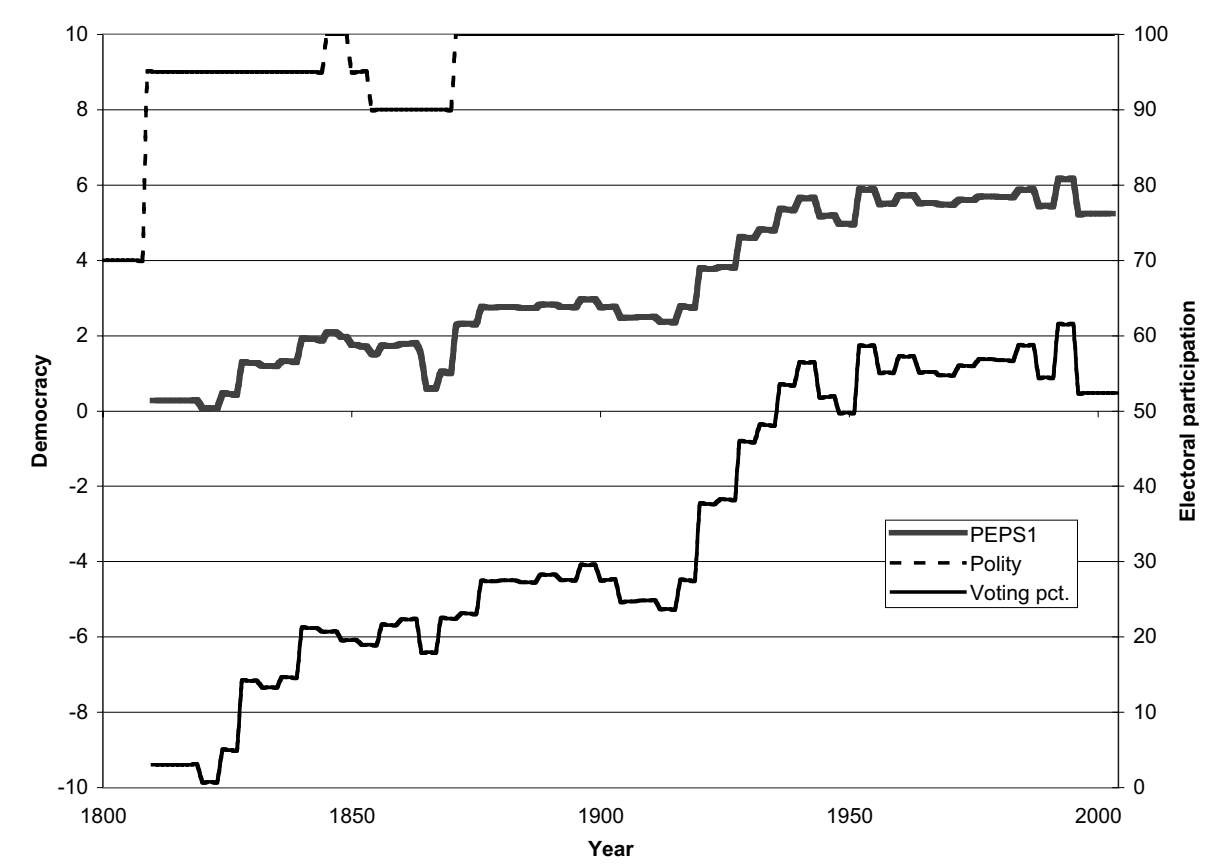


score at low levels of democracy. It prevents high voting turnouts, including those inflated by false reporting or harsh compulsory voting laws, from producing an unwarranted high score on participatory democracy among autocracies. ${ }^{22}$ While conceptually attractive, the result is a measure that does not differ from the Polity score for the 48 percent of the nation-years with zero scores on democracy in our sample.

We construct an alternative variable, PEPS2, which does not so strongly prejudge the democratic character of participation within an autocratic institutional structure. We compute PEPS2 as the average of the Polity score and the VTS, after the latter's $0-100$ range is scaled to match the former's -10 to $+10 .{ }^{23}$ Whereas PEPS1 may be thought of as a fully continuous extension of Polity's coarse categorization of participation, PEPS2 is designed as an index combining the institutional and participation facets of democracy in a more equal weighting. Specifically,

$$
\operatorname{PEPS}_{i, t}=\left(\left(\left(\mathrm{VTS}_{i, t} / .05\right)-10\right)+\text { Polity }_{i, t}\right) / 2
$$

In principle, PEPS2 permits much greater differentiation among countries at low levels of democracy than does PEPS1, whereas the two versions differ from one another only fractionally among nations with high Polity scores. In practice, IDEA's exclusion of noncompetitive elections results in a high incidence of missing data among the most autocratic nations. Thus, these cases are omitted from analyses involving our PEPS2 measure. Because this reduces our sample and constrains the generality of our results, we have constructed an alternative measure of PEPS2 in which these countries are assigned a zero score, but we report results using them only in the notes and in Table $2 .^{24}$

Table 2 lists all the available scores for 2003. The PEPS2 scores in bold were computed using a zero participation score for those nations lacking voting data, which would otherwise be recorded as missing data. ${ }^{25}$ The results of our new measurement may prove shocking to some, whereas the traditional democratic leaders of the pack no longer lead. The top 35 countries listed all score a perfect 10 with Polity, yet none score a perfect 10 with PEPS1 or PEPS2. The surprisingly low scores of well-known established democracies such as the United States and Switzerland are due to the very low voter turnout in recent elections. While the political institutions of these countries might set the standard for others to aspire to, we just cannot square turnout rates below 50 percent with any reasonable understanding of universal participation.

The discussion above establishes the "face validity" of our measures of participatory democracy. The remainder of the paper spells out the benefits of using those measures and, in the process, demonstrates their reliability and validity. Several methods of establishing "construct validity" are available for new measures of wellknown concepts whose existing operationalizations have been used in previous research. The first, "internal construct validation" or "convergent validity" requires a demonstration that the measures are collinear with existing indicators of the same concept also widely assumed to have face validity. ${ }^{26}$

Accordingly, Table 3 presents the correlations of participatory democracy scores and their components with the indexes of democracy and their components from three leading data projects, the Polity Project of Jaggers and Gurr (1995), the Free- 
Table 2

Voter Turnout, Polity, PEPS1, and PEPS2 Scores for All Countries in 2003

\begin{tabular}{|c|c|c|c|c|c|}
\hline & Country & Turnout & Polity & PEPS1 & PEPS2 \\
\hline 1 & Mongolia & $97 \%$ & 10 & 9.70 & 9.70 \\
\hline 2 & Uruguay & $95 \%$ & 10 & 9.47 & 9.47 \\
\hline 3 & Iceland & $91 \%$ & 10 & 9.08 & 9.08 \\
\hline 4 & Greece & $89 \%$ & 10 & 8.90 & 8.90 \\
\hline 5 & Belgium & $89 \%$ & 10 & 8.88 & 8.88 \\
\hline 6 & Italy & $85 \%$ & 10 & 8.49 & 8.49 \\
\hline 7 & Israel & $84 \%$ & 10 & 8.45 & 8.45 \\
\hline 8 & Australia & $84 \%$ & 10 & 8.38 & 8.38 \\
\hline 9 & Denmark & $84 \%$ & 10 & 8.35 & 8.35 \\
\hline 10 & Mauritius & $80 \%$ & 10 & 7.96 & 7.96 \\
\hline 11 & Netherlands & $78 \%$ & 10 & 7.81 & 7.81 \\
\hline 12 & Sweden & $78 \%$ & 10 & 7.78 & 7.78 \\
\hline 13 & Cyprus & $78 \%$ & 10 & 7.76 & 7.76 \\
\hline 14 & Finland & $77 \%$ & 10 & 7.68 & 7.68 \\
\hline 15 & Austria & $74 \%$ & 10 & 7.38 & 7.38 \\
\hline 16 & Spain & $74 \%$ & 10 & 7.38 & 7.38 \\
\hline 17 & Norway & $73 \%$ & 10 & 7.31 & 7.31 \\
\hline 18 & Germany & $73 \%$ & 10 & 7.26 & 7.26 \\
\hline 19 & New Zealand & $72 \%$ & 10 & 7.25 & 7.25 \\
\hline 20 & Slovenia & $72 \%$ & 10 & 7.23 & 7.23 \\
\hline 21 & Portugal & $70 \%$ & 10 & 7.01 & 7.01 \\
\hline 22 & Trinidad & $69 \%$ & 10 & 6.95 & 6.95 \\
\hline 23 & Ireland & $67 \%$ & 10 & 6.72 & 6.72 \\
\hline 24 & Costa Rica & $64 \%$ & 10 & 6.42 & 6.42 \\
\hline 25 & Poland & $63 \%$ & 10 & 6.26 & 6.26 \\
\hline 26 & Czech Republic & $59 \%$ & 10 & 5.85 & 5.85 \\
\hline 27 & United Kingdom & $58 \%$ & 10 & 5.76 & 5.76 \\
\hline 28 & Luxembourg & $57 \%$ & 10 & 5.69 & 5.69 \\
\hline 29 & Japan & $56 \%$ & 10 & 5.65 & 5.65 \\
\hline 30 & Hungary & $56 \%$ & 10 & 5.58 & 5.58 \\
\hline 31 & Canada & $55 \%$ & 10 & 5.46 & 5.46 \\
\hline 32 & Lithuania & $55 \%$ & 10 & 5.45 & 5.45 \\
\hline 33 & United States & $49 \%$ & 10 & 4.93 & 4.93 \\
\hline 34 & Switzerland & $38 \%$ & 10 & 3.78 & 3.78 \\
\hline 35 & Papua New Guinea & & 10 & & 5.00 \\
\hline 36 & Macedonia & $85 \%$ & 9 & 7.65 & 8.00 \\
\hline 37 & Slovakia & $79 \%$ & 9 & 7.12 & 7.42 \\
\hline 38 & Peru & $79 \%$ & 9 & 7.07 & 7.36 \\
\hline 39 & Taiwan & $78 \%$ & 9 & 6.98 & 7.26 \\
\hline 40 & Panama & $76 \%$ & 9 & 6.87 & 7.13 \\
\hline 41 & Chile & $73 \%$ & 9 & 6.55 & 6.78 \\
\hline 42 & Bulgaria & $72 \%$ & 9 & 6.49 & 6.71 \\
\hline 43 & France & $72 \%$ & 9 & 6.46 & 6.68 \\
\hline 44 & Thailand & $70 \%$ & 9 & 6.31 & 6.51 \\
\hline 45 & India & $65 \%$ & 9 & 5.89 & 6.05 \\
\hline 46 & South Africa & $64 \%$ & 9 & 5.75 & 5.89 \\
\hline 47 & Jamaica & $46 \%$ & 9 & 4.14 & 4.10 \\
\hline 48 & Botswana & $42 \%$ & 9 & 3.78 & 3.70 \\
\hline 49 & Nicaragua & $89 \%$ & 8 & 7.10 & 7.87 \\
\hline
\end{tabular}


Table 2 (Continued)

\begin{tabular}{|c|c|c|c|c|c|}
\hline & Country & Turnout & Polity & PEPS1 & PEPS2 \\
\hline 50 & Brazil & $83 \%$ & 8 & 6.63 & 7.28 \\
\hline 51 & Argentina & $80 \%$ & 8 & 6.36 & 6.95 \\
\hline 52 & Korea South & $71 \%$ & 8 & 5.70 & 6.12 \\
\hline 53 & Philippines & $69 \%$ & 8 & 5.52 & 5.90 \\
\hline 54 & Bolivia & $67 \%$ & 8 & 5.32 & 5.65 \\
\hline 55 & Dominican Republic & $65 \%$ & 8 & 5.23 & 5.53 \\
\hline 56 & Moldova & $64 \%$ & 8 & 5.10 & 5.38 \\
\hline 57 & Romania & $62 \%$ & 8 & 4.97 & 5.22 \\
\hline 58 & Lesotho & $60 \%$ & 8 & 4.81 & 5.01 \\
\hline 59 & Mexico & $60 \%$ & 8 & 4.80 & 5.00 \\
\hline 60 & Latvia & $54 \%$ & 8 & 4.35 & 4.44 \\
\hline 61 & Paraguay & $53 \%$ & 8 & 4.21 & 4.26 \\
\hline 62 & Guatemala & $49 \%$ & 8 & 3.92 & 3.90 \\
\hline 63 & Senegal & $41 \%$ & 8 & 3.29 & 3.12 \\
\hline 64 & Kenya & $39 \%$ & 8 & 3.15 & 2.93 \\
\hline 65 & Albania & $100 \%$ & 7 & 7.00 & 8.50 \\
\hline 66 & Indonesia & $86 \%$ & 7 & 5.86 & 7.07 \\
\hline 67 & Croatia & $74 \%$ & 7 & 5.20 & 5.93 \\
\hline 68 & Ukraine & $74 \%$ & 7 & 5.16 & 5.88 \\
\hline 69 & Turkey & $75 \%$ & 7 & 5.00 & 6.00 \\
\hline 70 & Russia & $69 \%$ & 7 & 4.82 & 5.38 \\
\hline 71 & Honduras & $69 \%$ & 7 & 4.80 & 5.36 \\
\hline 72 & Madagascar & $55 \%$ & 7 & 3.82 & 3.96 \\
\hline 73 & Colombia & $44 \%$ & 7 & 3.05 & 2.86 \\
\hline 74 & El Salvador & $38 \%$ & 7 & 2.67 & 2.31 \\
\hline 75 & East Timor & $100 \%$ & 6 & 6.00 & 8.00 \\
\hline 76 & Malawi & $87 \%$ & 6 & 5.08 & 8.00 \\
\hline 77 & Ecuador & $79 \%$ & 6 & 4.73 & 5.88 \\
\hline 78 & Bangladesh & $75 \%$ & 6 & 4.52 & 5.53 \\
\hline 79 & Sri Lanka & $78 \%$ & 6 & 4.49 & 5.85 \\
\hline 80 & Guyana & $73 \%$ & 6 & 4.35 & 5.26 \\
\hline 81 & Benin & $65 \%$ & 6 & 3.88 & 4.47 \\
\hline 82 & Namibia & $62 \%$ & 6 & 3.73 & 4.22 \\
\hline 83 & Mozambique & $59 \%$ & 6 & 3.57 & 3.94 \\
\hline 84 & Ghana & $65 \%$ & 6 & 3.52 & 4.46 \\
\hline 85 & Venezuela & $47 \%$ & 6 & 2.80 & 2.67 \\
\hline 86 & Serbia \& Montenegro & $46 \%$ & 6 & 2.77 & 2.62 \\
\hline 87 & Estonia & $47 \%$ & 6 & 2.32 & 2.74 \\
\hline 88 & Mali & $33 \%$ & 6 & 1.96 & 1.27 \\
\hline 89 & Sierra Leone & $89 \%$ & 5 & 4.44 & 6.38 \\
\hline 90 & Fiji & $78 \%$ & 5 & 3.65 & 5.25 \\
\hline 91 & Armenia & $72 \%$ & 5 & 3.59 & 4.67 \\
\hline 92 & Georgia & $65 \%$ & 5 & 3.26 & 4.02 \\
\hline 93 & Niger & $96 \%$ & 4 & 3.85 & 6.62 \\
\hline 94 & Nigeria & $75 \%$ & 4 & 2.99 & 4.47 \\
\hline 95 & Comoros & $33 \%$ & 4 & 1.31 & 0.27 \\
\hline 96 & Iran & $86 \%$ & 3 & 2.46 & 5.14 \\
\hline 97 & Malaysia & $50 \%$ & 3 & 0.98 & 1.46 \\
\hline 98 & Cambodia & $83 \%$ & 2 & 1.50 & 4.34 \\
\hline 99 & Tanzania & $53 \%$ & 2 & 0.59 & 1.31 \\
\hline 100 & Djibouti & $29 \%$ & 2 & -0.13 & -1.10 \\
\hline 101 & Ethiopia & $60 \%$ & 1 & -0.20 & 1.50 \\
\hline
\end{tabular}


Table 2 (Continued)

\begin{tabular}{|c|c|c|c|c|c|}
\hline & Country & Turnout & Polity & PEPS1 & PEPS2 \\
\hline 102 & Zambia & $36 \%$ & 1 & -0.92 & -0.91 \\
\hline 103 & Burkina Faso & $47 \%$ & 0 & -1.06 & -0.31 \\
\hline 104 & Guinea & $100 \%$ & -1 & -1.00 & 4.50 \\
\hline 105 & Cen. African Rep & $89 \%$ & -1 & -1.11 & 3.36 \\
\hline 106 & Guinea-Bissau & $63 \%$ & -1 & -1.37 & 0.76 \\
\hline 107 & Togo & $100 \%$ & -2 & -2.00 & 4.00 \\
\hline 108 & Yemen & $77 \%$ & -2 & -2.23 & 1.67 \\
\hline 109 & Chad & $70 \%$ & -2 & -2.30 & 1.00 \\
\hline 110 & Haiti & $61 \%$ & -2 & -2.39 & 0.05 \\
\hline 111 & Jordan & $49 \%$ & -2 & -3.02 & -1.09 \\
\hline 112 & Singapore & $21 \%$ & -2 & -3.57 & -3.86 \\
\hline 113 & Rwanda & $100 \%$ & -3 & -3.00 & 3.50 \\
\hline 114 & Tajikistan & $86 \%$ & -3 & -3.14 & 2.06 \\
\hline 115 & Kyrgyzstan & $74 \%$ & -3 & -3.26 & 0.93 \\
\hline 116 & Algeria & $64 \%$ & -3 & -3.36 & -0.12 \\
\hline 117 & Angola & & -3 & & -6.50 \\
\hline 118 & Uganda & $74 \%$ & -4 & -4.00 & 0.42 \\
\hline 119 & Congo & $74 \%$ & -4 & -4.00 & 0.42 \\
\hline 120 & Gabon & $55 \%$ & -4 & -4.00 & -1.52 \\
\hline 121 & Tunisia & $56 \%$ & -4 & -4.44 & -1.43 \\
\hline 122 & Cameroon & $55 \%$ & -4 & -4.45 & -1.50 \\
\hline 123 & Gambia & $64 \%$ & -5 & -5.00 & -1.06 \\
\hline 124 & Pakistan & $41 \%$ & -5 & -5.00 & -3.43 \\
\hline 125 & Eq. Guinea & & -5 & -5.00 & -7.50 \\
\hline 126 & Kazakhstan & $71 \%$ & -6 & -6.00 & -0.89 \\
\hline 127 & Mauritania & $49 \%$ & -6 & -6.00 & -3.07 \\
\hline 128 & Morocco & $41 \%$ & -6 & -6.00 & -3.93 \\
\hline 129 & Egypt & $30 \%$ & -6 & -6.00 & -4.96 \\
\hline 130 & Sudan & & -6 & -6.00 & \\
\hline 131 & Nepal & $76 \%$ & -6 & -6.24 & -0.42 \\
\hline 132 & Belarus & $81 \%$ & -7 & -7.00 & -0.37 \\
\hline 133 & Azerbaijan & $61 \%$ & -7 & -7.00 & -2.38 \\
\hline 134 & Zimbabwe & $50 \%$ & -7 & -7.00 & -3.52 \\
\hline 135 & Kuwait & $7 \%$ & -7 & -7.00 & -7.85 \\
\hline 136 & Myanmar & & -7 & -7.00 & -8.50 \\
\hline 137 & Eritrea & & -7 & -7.00 & -8.50 \\
\hline 138 & Vietnam & & -7 & -7.00 & -8.50 \\
\hline 139 & Laos & & -7 & -7.00 & -8.50 \\
\hline 140 & Cuba & & -7 & -7.00 & -8.50 \\
\hline 141 & Bahrain & & -7 & -7.00 & -8.50 \\
\hline 142 & Libya & & -7 & -7.00 & -8.50 \\
\hline 143 & China & & -7 & -7.00 & -8.50 \\
\hline 144 & Syria & & -7 & -7.00 & -8.50 \\
\hline 145 & UAE & & -8 & -8.00 & -9.00 \\
\hline 146 & Oman & & -8 & -8.00 & -9.00 \\
\hline 147 & Bhutan & & -8 & -8.00 & -9.00 \\
\hline 148 & Swaziland & & -9 & -9.00 & -9.50 \\
\hline 149 & Turkmenistan & & -9 & -9.00 & -9.50 \\
\hline 150 & Uzbekistan & & -9 & -9.00 & -9.50 \\
\hline 151 & Korea North & & -9 & -9.00 & -9.50 \\
\hline 152 & Saudi Arabia & & -10 & -10.00 & -10.00 \\
\hline 153 & Qatar & & -10 & -10.00 & -10.00 \\
\hline
\end{tabular}


dom House Project originated by Gastil (1972), and the Democracy Project of Vanhanen (2000). The convergent validity of the Participation Enhanced Polity Scores is established by their high correlations with each of the alternative measures. ${ }^{27}$

A different approach, known as "external construct validity," gauges the validity of a measure in terms of its empirical associations with concepts that are causally linked to it. This causal linkage should be firmly established in the theoretical literature and supported by uncontested empirical evidence. When the validity of the new measure is more open to question than the accuracy of the theoretical claim, the finding of a statistical relationship that is theoretically expected is properly interpreted as affirmation of the validity of the new measure. ${ }^{28}$ This procedure permits the identification of a stronger form of "predictive validity," or whether our measure produces a better prediction than existing ones.

In the next three sections, we choose three sets of phenomena to conduct external construct validity tests: one a known cause of democracy (development), one an internal attribute of democracy itself (its persistence over time, i.e., serial correlation that mirrors a "test-retest" approach to reliability), and two known consequences of democracy (the achievement of basic needs and gender equality).

\section{Democratization and Modernization: The Historical Record}

Among the most cited correlations in the social sciences is the tendency of rich nations to be more democratic. The robustness of this finding across numerous indicators, samples, and test procedures makes this an unusually solid comparison for external and predictive approaches to validation. The wide array of theoretical perspectives that anticipate an empirical relationship between democracy and de-

Table 3

Correlations between Participatory Democracy Scores and Democracy Indices

\begin{tabular}{|c|c|c|c|c|c|c|c|c|c|c|c|c|}
\hline & 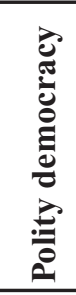 & 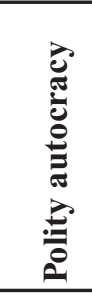 & : & 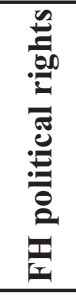 & 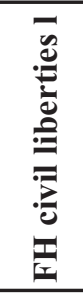 & 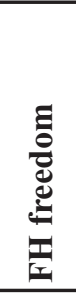 & 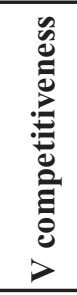 & 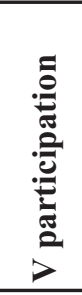 & 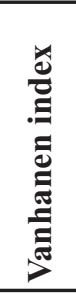 & 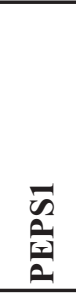 & 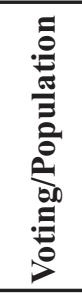 & 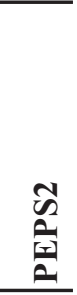 \\
\hline Polity Democracy & 1.00 & & & & & & & & & & & \\
\hline Polity Autocracy & 0.86 & 1.00 & & & & & & & & & & \\
\hline Polity3 & 0.97 & -0.96 & 1.00 & & & & & & & & & \\
\hline FH Political Rights & 0.92 & 0.87 & 0.92 & 1.00 & & & & & & & & \\
\hline FH Civil Liberties & 0.86 & 0.82 & 0.86 & 0.92 & 1.00 & & & & & & & \\
\hline FH Freedom & 0.91 & -0.86 & 0.91 & 0.98 & 0.98 & 1.00 & & & & & & \\
\hline V Competitiveness & 0.81 & -0.74 & 0.81 & 0.86 & 0.81 & 0.85 & 1.00 & & & & & \\
\hline V Participation & 0.49 & -0.38 & 0.45 & 0.50 & 0.47 & 0.50 & 0.51 & 1.00 & & & & \\
\hline Vanhanen Index & 0.77 & -0.65 & 0.74 & 0.83 & 0.80 & 0.83 & 0.81 & 0.74 & 1.00 & & & \\
\hline PEPS1 & 0.93 & -0.94 & 0.97 & 0.92 & 0.88 & 0.92 & 0.81 & 0.57 & 0.85 & 1.00 & & \\
\hline Voting/Population & 0.48 & -0.38 & 0.45 & 0.49 & 0.46 & 0.48 & 0.50 & 0.98 & 0.71 & 0.55 & 1.00 & \\
\hline PEPS2 & 0.85 & -0.79 & 0.85 & 0.81 & 0.76 & 0.81 & 0.77 & 0.84 & 0.85 & 0.90 & 0.85 & 1.00 \\
\hline
\end{tabular}


velopment provides additional confidence. Since Lipset's (1959) original formulation, nearly identical predictions have been generated from both refinements of modernization theory and theoretical challenges to it (Rostow, 1971; Bollen, 1983; Inkeles, 1998; Huber et al., 1993). In what has become known as the "endogenous" explanation, a range of structural conditions that accompany rising incomes are said to undercut autocracy and promote the adoption of democracy: education, urbanization, changing class structures, technological growth, and others. Adam Przeworski and Fernando Limongi (1997: 156) portray it this way:

\begin{abstract}
A story told about country after country is that as they develop, social structure becomes complex, labor processes begin to require the active cooperation of employees, and new groups emerge and organize. As a result, the system can no longer be effectively run by command: the society is too complex, technological change endows the direct producers with some autonomy and private information, civil society emerges, and dictatorial forms of control lose their effectiveness. Various groups, whether the bourgeoisie, workers, or just the amorphous "civil society," rise against the dictatorial regime, and it falls. ${ }^{29}$
\end{abstract}

Countless studies have confirmed the correlation between economic development and democracy, most using logged GDP per capita as the independent variable (Jackman, 1973; Lipset, 1959, 1994; Bollen, 1983; Huntington, 1987; Bhagwati, 1992; Barro, 1996; Burkhardt and Lewis-Beck, 1994; Lipset, Seong, and Torres 1993). This body of work serves as a control of sorts by establishing an outcome against which we can compare our new measures. If our measures do not exhibit the same close relationship with logged GDP, then they should be questioned. By contrast, if the relationship is closer than other democracy measures, we may reasonably conclude that we have captured essential elements that others have not.

We test this premise in a cross-sectional analysis by estimating equations (4) through (6) on two different samples.

$$
\begin{aligned}
& \text { Polity }_{i, t}=\alpha_{1}+\beta_{1} \ln \left(\text { GDPcap }_{i, t}\right)+\in_{t} \\
& \text { PEPS }_{i, t}=\alpha_{2}+\beta_{2} \ln \left(\text { GDPcap }_{i, t}\right)+\mu_{1 t} \\
& \text { PEPS }_{i, t}=\alpha_{3}+\beta_{3} \ln \left(\text { GDPcap }_{i, t}\right)+\mu_{2 t}
\end{aligned}
$$

The first estimation, reported in Table 4, is conducted over the seven years for which Angus Maddison (2001) provides GDP data, using turnout data from Vanhanen (2000). In all seven years, PEPS2 is more closely related to income than is Polity and, in six of the seven years, PEPS1 also fits the data better than the Polity measure.

We conducted a similar analysis for each year from 1950 through 2000, using IDEA voting data and Penn World Tables real GDP. ${ }^{30}$ In 49 of 51 years, PEPS1 yields higher $r^{2}$ values than polity, while PEPS2 was more closely related to GDP per capita than Polity in 48 cases. Polity produced a higher correlation than both in only two of the 51 years. ${ }^{31}$ While not conclusive evidence for the superiority of the Participation Enhanced Polity Scores, these results lend credence to our argument by showing that the theoretically expected and frequently confirmed cross-sectional 
Table 4

Cross-Sectional OLS Regression of Democracy on Logged GDP

\begin{tabular}{lcccc}
\hline Year & \# of Obs. & $\begin{array}{c}\text { Polity } \\
\mathbf{r}^{\mathbf{2}}\end{array}$ & $\begin{array}{c}\text { PEPS1 } \\
\mathbf{r}^{\mathbf{2}}\end{array}$ & $\begin{array}{c}\text { PEPS2 } \\
\mathbf{r}^{2}\end{array}$ \\
\hline 1820 & 12 & .053 & .034 & .055 \\
1870 & 24 & .226 & .262 & .246 \\
1913 & 30 & .338 & .377 & .476 \\
1950 & 74 & .324 & .417 & .441 \\
1973 & 126 & .216 & .245 & .226 \\
1990 & 128 & .430 & .493 & .479 \\
1998 & 144 & .210 & .273 & .300 \\
\hline
\end{tabular}

relationship between democracy and income emerges more clearly with PEPS than with Polity. ${ }^{32}$

\section{The Persistence of Democracy: Does Participation Matter?}

Having shown the greater cross-sectional variance found in PEPS can be accounted for by accepted theory, we now demonstrate the more frequent cross-time changes in PEPS also measure real differences rather than merely noise. To do so, we take advantage of another well-known property of political systems: the best prediction of a nation's level of democracy is invariably its own lagged value. The internal logic of the complex interlocking changes constituting democratization provides a powerful momentum that appears statistically as strong serial correlation. Following Elkins (2000), we argue the more finely-graded PEPS is superior to Polity if the additional detail it contains provides useful forecasting information. Challenging the prediction of serial correlation is surely a daunting task for any alternative indicator.

This measurement stance invokes an underlying theoretical contention: that participation itself drives change in other components of democracy. We expect participation to be a "leading indicator" of change in authority relations because broad citizen participation exerts pressure toward greater institutionalized democracy, whereas low participation allows authority relations to slide in an authoritarian direction. ${ }^{33}$ The conviction that empowered citizens will choose institutions that embody democratic authority relations is central to the utilitarian defense of democracy as a superior political system. If true, participation is a key component of democracy not only because it makes democracy more complete at present, but also because it makes it more likely to endure and even progress in the future.

To test whether electoral participation predicts the future state of authority relations, we estimate a series of Granger-causality equations defined over various time periods and with differing lags (Granger, 1969; Freeman, 1983) ${ }^{34}$ In our first crosssectional time-series analysis, the sample contains 3,881 nation-years from 1950 to 2003, consisting of unbalanced panels from 4 to 54 years for 142 nations. We assume a lag of one year and estimate:

$$
\text { Polity }_{i, t}=\alpha+\rho * \text { Polity }_{i, t-1}+\beta_{1}^{*} \operatorname{VTS}_{i, t-1}+\in_{i}
$$

We expect to find a large value for $\rho$ but are most interested in whether $\beta_{I}$ achieves 
Table 5

Random Effects GLS Regression of Polity

\begin{tabular}{lccrl}
\hline & Coefficient & Std. Err. & $\boldsymbol{Z}$ & $\boldsymbol{P}>|\boldsymbol{z}|$ \\
\hline Lagged Polity & .9601 & .0044 & 216.06 & 0.000 \\
Lagged VTS & .7538 & .1455 & 5.18 & 0.000 \\
Constant & -.2854 & .0931 & -3.07 & 0.002 \\
\hline
\end{tabular}

$r \leq$ : within $=0.7999$ between $=0.9958$ overall $=0.9347$

statistical significance. Polity is indeed strongly serially correlated, as represented by the coefficient of .96 and $z$ of 216.06 in the first row of Table 5. However, the coefficient of the lagged participation variable attains a $z$ of 5.18, significant well past $.001 .^{35}$ Even in the presence of the lagged dependent variable, participation rates are strongly and positively related to future Polity scores. Nations with higher participation rates are likely to have more democratic authority relations a year later. ${ }^{36}$

To analyze the effect of participation across broader expanses of time we also use a design with a single discrete panel for each nation. This approach enables us to check the robustness of the above result across alternative formulations and to determine if a superior prediction can be obtained from PEPS, which combines the causally intertwined participation and institutional dimensions of democracy. Table 6 reports the result of estimating equations (8) through (11), where each analysis is conducted over a separate decade, beginning with the 1960 to 1970 interval. The dependent variable is the Polity score at the end of the decade, whereas the predictor variables are measured at the beginning of the decade.

$$
\begin{aligned}
& \text { Polity }_{i, t}=\alpha_{1}+\rho^{*} \text { Polity }_{t-10}+\in_{i} \\
& \text { Polity }_{i, t}=\alpha_{1}+\rho^{*} \text { Polity }_{t-10}+\beta_{1} * \text { VTS }_{t-10}+\epsilon_{i} \\
& \text { Polity }_{i, t}=\alpha_{1}+\beta_{1} * \text { PEPS }_{t-10}+\in_{i} \\
& \text { Polity }_{i, t}=\alpha_{1}+\beta_{1} * \text { PEPS }_{t-10}+\in_{i}
\end{aligned}
$$

In each column, the first analysis, labeled "Polity alone," represents the benchmark equation (8). In an attempt to improve upon the fit of this point of reference, the remaining analyses include the participation effect in three different ways. Equation (9), the second analysis reported in each column, adds the Voter Turnout Scalar to the previous estimation, emulating equation (7), but with a longer lag. Equations (10) and (11) duplicate (8), but substitute PEPS1 and PEPS2, respectively, for Polity as the predictor.

The results support our thesis. For each decade except the 1970s, VTS is positive and statistically significant, indicating that past participation rates help predict future Polity scores. For example, in the 1960s, the Polity score at the beginning of the decade could explain 55 percent of the variance in Polity at the end of the decade. Adding participation, noticeably improved the $r^{2}$ to .60 , with the $t$ value for VTS showing a significant 2.49. Both PEPS1 and PEPS2 alone are superior to Polity in 
Table 6

Estimation of Equations (8) - (11), 1960-2000

\begin{tabular}{|c|c|c|c|c|}
\hline & $\begin{array}{c}1960-1970 \\
N=\mathbf{5 0}\end{array}$ & $\begin{array}{c}1970-1980 \\
N=59\end{array}$ & $\begin{array}{c}1980-1990 \\
N=66\end{array}$ & $\begin{array}{c}1990-2000 \\
N=79\end{array}$ \\
\hline \multicolumn{5}{|c|}{ Polity Alone (Equation 8) } \\
\hline Coefficient & 0.81 & 0.87 & 0.54 & 0.57 \\
\hline$T$ & 7.68 & 8.82 & 6.51 & 8.06 \\
\hline$r^{2}$ & 0.55 & 0.58 & 0.40 & 0.46 \\
\hline \multicolumn{5}{|c|}{ Polity and VTS (Equation 9) } \\
\hline \multicolumn{5}{|l|}{ Polity } \\
\hline Coefficient & 0.69 & 0.83 & 0.48 & 0.51 \\
\hline$T$ & 6.13 & 7.97 & 5.66 & 6.89 \\
\hline VTS & & & & \\
\hline Coefficient & 9.34 & 4.47 & 7.43 & 5.67 \\
\hline$T$ & 2.49 & 1.35 & 2.24 & 2.17 \\
\hline$r^{2}$ & 0.60 & 0.59 & 0.44 & 0.49 \\
\hline \multicolumn{5}{|c|}{ PEPS1 Alone (Equation 10) } \\
\hline Coefficient & 0.98 & .98 & 0.64 & 0.67 \\
\hline$T$ & 8.69 & 8.66 & 6.70 & 8.43 \\
\hline$r^{2}$ & 0.61 & 0.57 & 0.41 & 0.48 \\
\hline \multicolumn{5}{|c|}{ PEPS2 Alone (Equation 11) } \\
\hline Coefficient & 1.23 & 1.25 & 0.90 & 0.88 \\
\hline$T$ & 8.45 & 8.12 & 7.09 & 8.40 \\
\hline$r^{2}$ & 0.60 & 0.54 & 0.44 & 0.48 \\
\hline
\end{tabular}

predicting its future value in every decade except the 1970s. ${ }^{37}$ Based on these findings, it is undeniable that including participation as an element of an overall democracy score pays dividends for the analysis of democratic persistence post-1960.

Is the same true for an earlier era, dating to the early nineteenth century? An analysis of the period allows us to look at lag times testing democratic persistence over periods far longer than the one-year and the one-decade intervals in the analyses above. We used the years contained in Maddison (2001) as our base points: 1820, 1870, 1913, 1950, 1973, 1990, and 1998, allowing a total of 21 different intervals that ranged from eight to 178 years. ${ }^{38}$

The first set of regressions, reported in the leftmost columns of Table 7, represent the benchmark estimation of equation (8) and Polity's ability to predict its own future values. The serial correlation is evidenced by $t$ values that are statistically significant in 15 of the 21 cases, with the strength of the relationship decreasing as the time horizons increase. ${ }^{39}$ The second pair of columns reports the results when our measure of voter turnout replaces Polity as the predictor variable. Fifteen of these coefficients are also statistically significant and, in 11 cases - more than halfturnout provides a better prediction of Polity's future than Polity itself does. Be- 
Table 7

Predicting Future Values of Polity

\begin{tabular}{|c|c|c|c|c|c|c|c|c|c|c|c|c|}
\hline \multicolumn{2}{|c|}{ Time Period } & \multicolumn{2}{|c|}{$\begin{array}{c}\text { Polity } \\
\text { Alone (8) }\end{array}$} & \multicolumn{2}{|c|}{$\begin{array}{l}\text { VTS } \\
\text { Alone }\end{array}$} & \multirow{2}{*}{\multicolumn{3}{|c|}{$\begin{array}{c}\begin{array}{c}\text { Polity and } \\
\text { VTS (9) }\end{array} \\
\text { Polity VTS }\end{array}$}} & \multicolumn{2}{|c|}{ PEPS1 (10) } & \multicolumn{2}{|c|}{ PEPS2 (11) } \\
\hline & \multirow[b]{2}{*}{$\mathbf{N}$} & \multirow[b]{2}{*}{$\mathbf{T}$} & \multirow[b]{2}{*}{$\mathbf{r}^{2}$} & \multirow[b]{2}{*}{ t } & \multirow[b]{2}{*}{$\mathbf{r}^{2}$} & & & & \multirow[b]{2}{*}{$\mathbf{t}$} & \multirow[b]{2}{*}{$\mathbf{r}^{2}$} & \multirow[b]{2}{*}{$\mathbf{t}$} & \multirow[b]{2}{*}{$\mathbf{r}^{2}$} \\
\hline & & & & & & $\mathbf{t}$ & $\mathbf{t}$ & $\mathbf{r}^{2}$ & & & & \\
\hline $1820-1870$ & 23 & 4.91 & 0.53 & 0.38 & 0.01 & 4.79 & -.37 & 0.54 & 3.91 & 0.42 & 4.88 & 0.53 \\
\hline $1820-1913$ & 22 & 2.75 & 0.27 & 2.53 & 0.24 & 2.58 & 2.36 & 0.44 & 2.64 & 0.26 & 2.84 & 0.29 \\
\hline $1820-1950$ & 22 & 0.46 & 0.01 & 1.86 & 0.15 & 0.17 & 1.76 & 0.15 & 0.00 & 0.00 & 0.52 & 0.01 \\
\hline $1820-1973$ & 23 & 0.12 & 0.00 & 1.82 & 0.14 & -0.21 & 1.79 & 0.14 & -0.46 & 0.01 & 0.18 & 0.00 \\
\hline $1820-1990$ & 23 & 1.18 & 0.06 & 1.21 & 0.07 & 0.97 & 1.00 & 0.11 & 1.24 & 0.07 & 1.21 & 0.07 \\
\hline 1820-1998 & 23 & 0.61 & 0.02 & 1.11 & 0.06 & 0.41 & 0.99 & 0.06 & 0.54 & 0.01 & 0.64 & 0.02 \\
\hline 1870-1913 & 44 & 3.43 & 0.22 & 4.40 & 0.32 & 2.59 & 3.67 & 0.41 & 3.26 & 0.20 & 4.41 & 0.32 \\
\hline $1870-1950$ & 45 & 2.23 & 0.10 & 2.52 & 0.13 & 1.54 & 1.90 & 0.17 & 2.01 & 0.09 & 2.67 & 0.14 \\
\hline 1870-1973 & 46 & 2.15 & 0.10 & 1.68 & 0.06 & 1.69 & 1.08 & 0.12 & 1.67 & 0.06 & 2.37 & 0.11 \\
\hline $1870-1990$ & 45 & 3.31 & 0.20 & 2.33 & 0.11 & 2.66 & 1.43 & 0.24 & 3.61 & 0.23 & 3.62 & 0.23 \\
\hline 1870-1998 & 46 & 1.54 & 0.05 & 2.28 & 0.11 & 0.90 & 1.86 & 0.12 & 1.74 & 0.06 & 1.97 & 0.08 \\
\hline $1913-1950$ & 52 & 4.88 & 0.32 & 5.65 & 0.39 & 2.59 & 3.58 & 0.46 & 4.53 & 0.29 & 6.18 & 0.43 \\
\hline $1913-1973$ & 53 & 3.39 & 0.18 & 4.17 & 0.25 & 1.55 & 2.70 & 0.29 & 2.93 & 0.14 & 4.23 & 0.26 \\
\hline $1913-1990$ & 52 & 2.15 & 0.08 & 2.49 & 0.11 & 1.00 & 1.56 & 0.13 & 1.98 & 0.07 & 2.58 & 0.12 \\
\hline 1913-1998 & 53 & 1.53 & 0.04 & 2.26 & 0.09 & 0.40 & 1.66 & 0.09 & 1.22 & 0.03 & 2.00 & 0.07 \\
\hline $1950-1973$ & 82 & 11.21 & 0.61 & 4.05 & 0.17 & 9.90 & 1.98 & 0.63 & 12.21 & 0.65 & 9.60 & 0.54 \\
\hline $1950-1990$ & 78 & 5.20 & 0.26 & 4.01 & 0.17 & 4.14 & 2.71 & 0.33 & 5.79 & 0.31 & 6.04 & 0.32 \\
\hline 1950-1998 & 81 & 3.83 & 0.16 & 3.94 & 0.16 & 2.68 & 2.81 & 0.23 & 4.37 & 0.19 & 4.91 & 0.23 \\
\hline 1973-1990 & 133 & 10.77 & 0.47 & 4.84 & 0.15 & 9.02 & 1.44 & 0.48 & 10.63 & 0.46 & 9.52 & 0.41 \\
\hline 1973-1998 & 133 & 8.14 & 0.34 & 4.50 & 0.13 & 6.55 & 1.61 & 0.35 & 8.08 & 0.33 & 7.72 & 0.31 \\
\hline 1990-1998 & 138 & 18.50 & 0.72 & 8.76 & 0.36 & 13.21 & 1.66 & 0.72 & 18.02 & 0.70 & 15.87 & 0.65 \\
\hline
\end{tabular}

cause they are generally those with the longest estimation intervals, it appears the impact of participation may not decay as rapidly as democracy's institutional component. ${ }^{40}$

The specification of equation (9) reinforces the importance of participation, as turnout remains a significant predictor across six of the intervals, even with the lagged dependent variable in the equation. The estimation of equation (10) reveals that PEPS1 is a significant predictor of Polity in 13 of 21 analyses; in six it outperformed Polity itself. The last column's report of equation (11) offers the most striking results: in 16 of 21 intervals, the relationship between Polity and lagged PEPS2 was significant; and the PEPS2 prediction was also superior to Polity's in 16 cases. $^{41}$

In short, we have strong evidence of a statistical relationship between earlier levels of participation and later levels of institutional democracy-over lags ranging from one to 178 years, estimated within three different model specifications, and using two different data sources. Moreover, we have shown both PEPS measures are at least as effective in predicting future Polity levels as lagged Polity itself, and frequently superior. If we adjudicate the question of the value of the additional detail contained in PEPS on the basis of whether it portends future democratic change, the conclusion is evident. Since higher participation makes a nation caus- 
ally closer to full democracy, the PEPS measures appropriately register it as conceptually closer as well. ${ }^{42}$

We know of no formal standard by which to judge whether these results are strong enough to justify the inclusion of participation in a measure of democracy. Yet this analysis surely adds to the external construct validity established by the demonstration that the PEPS measures perform closer to theoretical expectations as dependent variables than does Polity.

\section{Democracy, Basic Needs, and Gender Equality}

Our final series of tests of the predictive validity of PEPS concerns the effect of democracy, variously measured, on two social outcomes with a strong distributional component - the achievement of basic human needs and gender equality. There is little doubt that a democratic state can and should play a key role in shaping those outcomes; it is generally acknowledged that egalitarian outcomes require affirmative state action (Moon, 1991; Lindblom, 1977; Gough, 2000). Typical is Bruce E. Moon's (1991: 100) formulation:

If the natural propensity to inequality is to be minimized, the productive capacities of the economy must be directed toward the provision of basic needs. That direction must be accomplished outside a system dominated by the logic of capital accumulation and microeconomic rationality; that is, it must occur in the political realm.

Under what conditions will the state assume the orientation leading it to act in this way? In what Christopher Hewitt (1977) describes as the "simple democratic hypothesis," the "existence of democratic institutions - especially the enfranchisement of all citizens - virtually guarantees relatively egalitarian policies" (1991:132). Underlying the expectation that basic needs and gender equality will be provided more fully by democracies is the belief that "politicians seek to maximize their chances of election and thus derive their policy preferences from those of their constituents" (Lake and Baum, 2001: 589). By contrast, "benevolence among autocrats seems empirically rare."

All that is required to complete the logic of David R. Mayhew's (1974) "electoral connection" is the intuitive assumption that the political agenda of the poor will emphasize basic needs and the agenda of women will feature gender equality. If so, democratic institutions should translate these preferences into electoral power affecting state policy. If they do not, democratic states will find it difficult to maintain their legitimacy and politicians will not retain their authority.

Hewitt (1977: 451) also offers an alternative view when he states, "Political democracy is not a sufficient condition for the achievement of a more equal society. The crucial matter is what the mass electorate does with the franchise." Thus, he anticipates that democracy does not necessarily promote equality; it does so only when the electorate attaches priority to it.

Although there are certainly preference variations between different electorates, we suspect the apparently dissimilar effects of democracy in distinct settings are more a product of the degree of democracy actually present. ${ }^{43}$ We contend that the breadth of political participation is at least as important as the presence of demo- 
cratic institutions in bringing about outcomes benefiting the citizenry. Unless the poor actually participate, there is no magic in democratic institutions resulting in favorable outcomes for them. If women do not participate, democracy is only partial — and will not engender equality. As Dahl (1971: 29) points out, democracies "are no more considerate than other regimes toward people who are effectively excluded from the rights of citizens." Nor to those who do not exercise them. We test the effect of participation on these social outcomes by comparing the predictive value of alternative measures of democracy.

First, as a measure of basic needs attainment, we select an indicator comprised of the life expectancy and education indexes used by the United Nations Development Program (UNDP) to construct its well-known Human Development Index (HDI). We omit the HDI's third component, GDP per capita, because we use it on the right-hand side of the estimating equations. We took the data for 2003 directly from the UNDP web site. ${ }^{44}$

$$
\begin{aligned}
& \text { HumanDevelopment }_{i}=\alpha_{1}+\beta_{1}{ }^{*} \log (\text { GDP per capita })_{i}+\beta_{2}{ }^{*} \text { Polity }_{i}+\epsilon_{i} \\
& \begin{array}{l}
\text { HumanDevelopment } \\
+\beta_{3}{ }^{*} \text { VTS }_{i}+\epsilon_{1}+\beta_{1} * \log (\text { GDP per capita })_{i}+\beta_{2}{ }^{*} \text { Polity }_{i}
\end{array} \\
& \text { HumanDevelopment }_{i}=\alpha_{1}+\beta_{1}{ }^{*} \log (\text { GDP per capita })_{i}+\beta_{2}{ }^{*} \text { PEPS }_{i}+\epsilon_{i} \\
& \text { HumanDevelopment }_{i}=\alpha_{1}+\beta_{1} * \log (\text { GDP per capita })_{i}+\beta_{2}{ }^{*} \text { PEPS }_{i}+\epsilon_{i}
\end{aligned}
$$

Table 8 reports the results of five regressions, each using logged real GDP per capita and a different democracy measure to predict Human Development. In column (12), which uses Polity as the democracy measure, we see a result common to all previous studies of basic needs: human development rises along with economic development and increasing levels of democracy, though the latter does not quite attain statistical significance (Moon, 1991, Gough, 2000; Moon and Dixon, 1985).

The next column replaces Polity with our measure of participation, the VTS computed from IDEA data. The results are striking. The $t$ values demonstrate that participation is a far more significant predictor of Human Development than the

\begin{tabular}{|c|c|c|c|c|c|c|c|c|c|c|}
\hline \multirow[t]{2}{*}{$N=128$} & \multicolumn{2}{|c|}{ equation (12) } & \multicolumn{2}{|c|}{ VTS alone } & \multicolumn{2}{|c|}{ Equation (13) } & \multicolumn{2}{|c|}{ equation (14) } & \multicolumn{2}{|c|}{$\overline{\text { equation (15) }}$} \\
\hline & $\boldsymbol{\beta}$ & $\mathbf{t}$ & $\beta$ & $\mathbf{t}$ & $\beta$ & $\mathbf{t}$ & $\beta$ & $\mathbf{t}$ & $\beta$ & $\mathbf{t}$ \\
\hline LogGDPpc & 13.29 & 15.01 & 14.04 & 18.99 & 13.51 & 15.39 & 13.14 & 15.22 & 13.18 & 16.20 \\
\hline Polity & .319 & 1.65 & & & .218 & 1.12 & & & & \\
\hline VTS & & & 12.71 & 2.55 & 11.39 & 2.23 & & & & \\
\hline PEPS1 & & & & & & & .488 & 2.15 & & \\
\hline PEPS2 & & & & & & & & & .712 & 2.61 \\
\hline $\mathrm{r}^{2}$ & .739 & & & .747 & & 750 & .74 & & .74 & 48 \\
\hline
\end{tabular}
Polity measure of democratic institutions. Column (13), which reports the estimation that includes both these elements of democracy, confirms that participation

Table 8

Democracy and Human Development 
does matter-more so than democratic institutions, the $t$ value of which is not statistically significant. The remaining columns demonstrate that our two variants of the Participation Enhanced Polity Score are both better predictors of providing basic needs than is Polity. These results add empirical evidence to our conceptual argument - that the full effect of democracy on important social outcomes cannot be appreciated until participation is incorporated into its measure. The failure to do so risks underestimating democracy's positive effects and, perhaps more important, misunderstanding the pathway by which democracy accomplishes them.

Finally, we turn to gender equality. ${ }^{45}$ Numerous scholars have commented on the importance of gender in development, demonstrating that when women possess the same social, political, and economic opportunities as men, many positive development outcomes result (Klasen, 1999; Osmani and Sen, 2003; Nussbaum, 2000). According to Amartya Sen (1999), "Nothing, arguably, is as important today in the political economy of development as an adequate recognition of the political, economic, and social participation and leadership of women." Despite the importance of gender equality as a value in itself and as a spur to development, few rigorous cross-national studies have attempted to uncover its structural determinants. ${ }^{46}$ There is little agreement on how it should be conceptualized or measured. For the purpose of this study, we select the UNDP's gender-development index (GDI), which is more aptly described as a gendered version of the human development index than as a direct measure of gender equality itself. ${ }^{47}$ Given the link between democracy and other forms of equality, we adopt a design identical to that described above, estimating equations (16) through (19). We expect that democracy contributes to gender equality, especially when democracy is properly understood to encompass participation.

$$
\begin{aligned}
& \mathrm{GDI}_{i}=\alpha_{1}+\beta_{1}{ }^{*} \log (\mathrm{GDP} \text { per capita })_{i}+\beta_{2}{ }^{*} \text { Polity }_{\mathrm{i}}+\epsilon_{i} \\
& \mathrm{GDI}_{i}=\alpha_{1}+\beta_{1} * \log (\mathrm{GDP} \text { per capita })_{i}+\beta_{2}{ }^{*} \text { Polity }_{i}+\beta_{3}{ }^{*} \mathrm{VTS}_{i}+\epsilon_{i} \\
& \mathrm{GDI}_{i}=\alpha_{1}+\beta_{1}{ }^{*} \log (\mathrm{GDP} \text { per capita })_{i}+\beta_{2}{ }^{*} \mathrm{PEPS}_{i}+\epsilon_{i} \\
& \mathrm{GDI}_{i}=\alpha_{1}+\beta_{1} * \log (\mathrm{GDP} \text { per capita })_{i}+\beta_{2}{ }^{*} \mathrm{PEPS}_{i}+\epsilon_{i}
\end{aligned}
$$

Column (16) of Table 9 establishes that both economic development (logged real GDP per capita) and institutional democracy (Polity) are positively associated with gender equality, as expected, though the effect of the latter is weak. The remaining columns demonstrate a now familiar outcome. Our participation measure, the Voter Turnout Scalar, is a far better predictor of gender-sensitive development than is the Polity measure of democratic institutions. ${ }^{48}$ Its $t$-value is far higher when it is the sole democracy measure in the estimation and, as column (17) shows, Polity is not significant in the presence of the VTS. Column (18) demonstrates that PEPS1 is clearly superior to Polity, but column (19) shows that PEPS2 is better yet. We see that the most significant consequences of democracy - the welfare of citizens and the equality of their treatment - follow more from the breadth of political participation than from the mere presence of institutions. ${ }^{49}$ Our exercise in construct validation reveals important causal mechanisms in the effect of democracy on institutional stability and key social outcomes. ${ }^{50}$ 
Table 9

Democracy and Gender Equality

\begin{tabular}{|c|c|c|c|c|c|c|c|c|c|c|}
\hline \multirow[b]{2}{*}{$\mathrm{N}=\mathbf{1 1 7}$} & \multicolumn{2}{|c|}{ (16) } & \multicolumn{2}{|c|}{ VTS Alone } & \multicolumn{2}{|c|}{ (17) } & \multicolumn{2}{|c|}{ (18) } & \multicolumn{2}{|c|}{ (19) } \\
\hline & $\beta$ & $\mathbf{t}$ & $\beta$ & $\mathbf{t}$ & $\beta$ & $\mathbf{t}$ & $\beta$ & $\mathbf{t}$ & $\beta$ & $\mathbf{t}$ \\
\hline LogGDP pc & 14.70 & 23.65 & 14.95 & 29.70 & 14.77 & 24.35 & 14.55 & 23.99 & 14.43 & 25.12 \\
\hline Polity & .133 & 0.96 & & & .07 & 0.52 & & & & \\
\hline VTS & & & 10.01 & 2.76 & 9.68 & 2.63 & & & & \\
\hline PEPS1 & & & & & & & .25 & 1.50 & & \\
\hline PEPS2 & \multirow{2}{*}{\multicolumn{2}{|c|}{.881}} & \multirow{2}{*}{\multicolumn{2}{|c|}{.889}} & \multirow{2}{*}{\multicolumn{2}{|c|}{.888}} & & & & 2.24 \\
\hline $\mathrm{r}^{2}$ & & & & & & & & 83 & \multicolumn{2}{|c|}{.885} \\
\hline
\end{tabular}

\section{Conclusion}

Broad political participation is a core feature of democracy and crucial for its durability. Participation helps to shape collective identity, as well as achieve social justice and equality across class, gender, and ethnic cleavages. No measure of democracy can be considered an accurate representation of its basic character without directly including participation as a significant component. While we applaud increased attention to the extent of suffrage in a country, what matters most is the number of citizens who actually vote.

Our Participation Enhanced Polity Scores have passed the tests appropriate for new measures. We demonstrated through three examples-Great Britain, South Africa, and Switzerland - that PEPS offers a more accurate reflection of democratic qualities than existing measures. We demonstrated the reliability of PEPS by showing its close relationship with accepted alternatives. We validated it by comparing its empirical correlates in three kinds of studies. First, we confirmed the story of rising incomes leading to democracy is more vividly captured by PEPS than others. Second, we confirmed our hypothesis that countries with high levels of participation would be more likely to be democratic in the future and argued this pattern warrants including participation in a contemporary measure. Finally, we demonstrated PEPS was a better predictor of the provision of basic human needs and gender equality, characteristics theoretically associated with democracy. Based on these results, we can conclude the full effect of democracy on important social outcomes cannot be appreciated until participation is directly incorporated into its measure.

Our disquiet about measuring democracy is not just about the face validity of concepts. It is not merely aesthetics inducing our unease at labeling as perfectly democratic those polities restricting the full exercise of citizenship. It is because the campaign for democratic change must rely on accurate causal claims that we call on empirical researchers to employ a broader measurement of democracy than previous studies. We also offer this caution to those who would seek to build democratic systems to achieve the benefits associated with them: the breadth of political participation must have at least as high a priority as institutional structure. Voting counts! 


\section{Notes}

* We are grateful for the helpful suggestions of Frank Davis, Bill Dixon, Chaim Kaufmann, Rajan Menon, Pamela Paxton, Larry Taylor, and the anonymous reviewers.

1. It is rare to find one democracy that is exactly like any another. For the breadth of modern conceptions of democracy, see Pieterse (2002). For empirical variations, see the ACE Project (2003).

2. Because most conceptions acknowledge that complex political systems cannot reach perfection, most scholars eschew a democracy/autocracy dichotomy in favor of a gradation approach to measurement (Elkins, 2000).

3. Specifically, a polity's authority structure can be analyzed in terms of: (1) the influence relations between superordinate and subordinate strata, (2) the degree of inequality between them, (3) the institutional relations among superordinates, (4) the competitiveness of recruitment, and (5) the basis of political legitimacy.

4. It codes all independent countries with populations greater than 500,000 and extends from 1801 to 2003 .

5. Paxton is particularly and accurately condemning, noting that while major measures of democracy claim "universal suffrage as a consideration, women are normally excluded from this definition."

6. Gleditsch and Ward (1997: 380) similarly show that "the extent and competitiveness of participation are not especially powerful in determining the degree of democracy or autocracy in modern polities as reflected by the Polity data set."

7. Participatory democracy shares the ideal of empowerment that pervades the contemporary development literature (Chambers, 1997; Bebbington, 1999; Freire, 1998; Scoones, 1998).

8. Just as democratic institutions can coexist with restricted participation, high levels of participation can be found without restraints on executive authority or respect for minority rights, as discussed by the literature on "illiberal democracy" (Zakaria, 1997).

9. Breadth measures the horizontal pervasiveness of politics within a governed population, which we conceive as how many people interact with the political system, not how they interact with the system. Our concern with the breadth of citizen participation is reflected in our emphasis upon electoral participation. We do not mean to deny the importance of the depth of citizen participation as manifested in such phenomena as lobbies, special interest groups, etc. These are the social networks, community organizations and civic associations laid out by Robert Putnam (1993) as a part of a state's social capital. Putnam's idea of social capital also includes other manifestations of citizen participation that are not necessarily political in nature, such as choral societies, sports clubs, and community service organizations. Our decision is based principally upon data availability, but it is also justified by a distinction between activities that are state-centered and those lodged within civil society.

10. Figure 1 shows voter turnout data from Vanhanen (2000) adjusted to reflect voting age population.

11. Another is that Switzerland, like many other countries, has a high incidence of noncitizens ineligible to vote.

12. For example, refusing the vote to convicts results in a subtraction of .50, whereas a deduction of .25 occurs when a restriction is placed on voting rights of the mentally disabled. McDonald and Popkin (2001) show that such fixed estimates distort conclusions because the percentage of the population that fits these categories varies markedly over time. Cross-sectional variation is probably much larger.

13. Examples of incentives and disincentives built into institutions include registration laws, residency requirements, and the location of polling places (Powell, 1986). Turnout is discouraged by single member districts, disproportionality in translating votes to legislative seats, multipartyism, and bicameralism (Jackman, 1987). Postal voting, absentee and advance voting, weekend elections, and longer poll hours encourage it (Franklin, 1996). Other factors that increase votingand indicate the breadth of the democracy - include citizen attitudes that reflect political culture and individual experience with the political system, such as partisanship, feelings of efficacy, trust in institutions, and interest in public affairs. The competitiveness of elections and the likelihood of change due to elections also spur turnout (Mahler, 2002; Franklin, 1996).

14. The sample was comprised of more than 4,000 nation-years from 1950 to 2000 for which data 
exists on both measures. The overall Polity score described above explains a considerably higher proportion of the variance in votes cast, a result that also holds in additional analyses with various other predictors included in the estimation equation.

15. IDEA identifies only four countries that include imprisonment among possible penalties and only one of these-Fiji-is said to have strict enforcement. Also, any imprisonment enforced would be the result of a failure to pay fines (after given notices and warnings) and not the result of a failure to vote. IDEA could find no evidence that imprisonment had ever occurred as punishment in any nation.

16. The others were either not enforced, or IDEA could not determine the level of enforcement.

17. Previous studies have produced various conclusions. IDEA (2003) finds that nations that have some element of compulsion associated with voting have only a small lead in turnout, and that the effects of electoral systems, the competitiveness of elections, and socioeconomic factors are larger. Pérez-Liñán (2001) finds no significant effect within Latin America. Blais and Dobrzynska (1998) find a parameter estimate of between 10 and 12 percent. Franklin (1996) finds the effect to be about 7 percent, roughly similar to that of postal voting and Sunday voting, but considerably smaller than the proportionality of the system and the salience of the election. See also the review in Lijphart (1997).

18. The most rudimentary measure is voter turnout as a percentage of the total population. Vanhanen (2000) uses this measure, but acknowledges that it introduces substantial bias because adults represent a highly variable percentage of the population across nations and over time. Following both IDEA (2003) and Paxton and Bollen (2002), we mark the age of majority at 18, even though the actual voting age varies widely, especially in earlier eras.

19. IDEA reports elections from 1945 to 2003, which leaves no basis on which to code participation for the years between 1945 and the next election; thus, we begin in 1950. Because IDEA's data is fragmentary after 2000, we updated the records for later years, largely using the same sources as IDEA. IDEA's estimate of adult population is mostly based on data reported by UN Department of Economic and Social Affairs.

20. The Vanhanen dataset is constructed as a year-by-year profile of each country. When no votes were reported, we treated the case as missing data, but we accepted as valid a zero entry. To achieve some degree of comparability, but lacking demographic data, we multiply Vanhanen's estimate of total population by two-thirds as a crude estimate of the adult population. Our data treatment procedures are detailed on our project webpage, http://www.lehigh.edu/ bm05/democracy/

21. In the process of increasing the role of participation, the influence of executive constraints identified by Gleditsch and Ward (1997) is reduced significantly by PEPS1 and even more by PEPS2. It remains that multiple combinations of subdimensions can yield the same overall score, as in any mapping to a single data point.

22. An additional advantage of this construction is that it permits the computation of valid PEPS1 scores for nations with a zero level of democracy regardless of the availability of voting data.

23. The Polity score is a variant of Polity 2 in which nations undergoing an interregnum are treated as missing data points rather than the zero value. See Marshall and Jaggers (2001) and our web site for details.

24. IDEA does not distinguish between a "non-competitive" election and no election at all. Furthermore, it is not clear theoretically whether voting in "non-competitive" elections should be considered to constitute "participation" in any meaningful sense.

25. This process boosts the number of nation-years for which a PEPS2 score can be computed by about 50 percent, but it adds only about 3 percent for PEPS1 because most nations without voting data have a zero score on democracy.

26. Munck and Verkuilen (2002a) contend that comparisons between a new measure and existing ones can establish reliability, but not validity. To be reliable, a measure must be fully reproducible by an independent drawing on the same sources. But this position does not take into account the collective validity accorded to these measures by the expert acceptance reflected in their widespread use.

27. The pairwise correlations represent the sample of all available scores for the period 1800 to the present, encompassing a total of 15,785 nation-years. Since Freedom House covers only the period since 1972, most of the correlations involving those variables are computed over about 
4,000 cases. To avoid confusion over signs, the Freedom House variables have been rescaled so that higher numbers indicate higher levels of democracy.

28. Adcock and Collier (2000) call this the "AHEM validity test" (Assume the Hypothesis, Evaluate the Measure).

29. Przeworski takes the cross-sectional relationship as a given, but challenges the "endogenous" explanation for it (Przeworski and Limongi, 1997; Przeworski et al., 2000). His "exogenous" account contends that democracy arises as frequently in poor countries as in rich ones, but that "once established, democracies are likely to die in poor countries and certain to survive in wealthy ones" Przeworski and Limongi (1997:167). This rejection of the endogenous explanation is itself refuted conceptually, theoretically, and empirically by Boix and Stokes (2003) and Hadenius and Teorell (2005). Despite these different explanations, all accept as valid the strong relationship between democracy and development.

30. The results, reported in a table comparable to Table 4, are available from the authors.

31. When the absence of competitive elections is considered zero participation rather than missing data, the sample size for analysis increases markedly and changes character, because it now includes a larger number of very autocratic nations. Measures of PEPS2 computed under that premise show higher $r^{2}$ values than Polity in 37 of 51 cases while Polity1, much less affected by missing voting data, continues to do so in 48 of 51 cases.

32. Longitudinal analysis was attempted using Prais-Winsten time-series techniques, which are close derivatives of linear regression models. The results were inconclusive, due to problems of collinearity associated with unchanging (i.e., $y(t)=y(t+1)$ ) Polity Scores and a tendency for nonconvergence in the Prais-Winsten iterations.

33. The reverse is also true. When authority relations become more democratic, participation grows This occurs both because institutional change may afford enhanced opportunities and because citizens are more willing to incur the opportunity costs (and other risks of participation) when institutions make participation significant for policy choice.

34. Lodging the analysis within a discussion of measurement issues makes clear that we are as interested in statistical predictability as in formal causal claims, however.

35. The recoded turnout measure produces a $\mathrm{z}$ of 6.22 and an overall $r^{2}$ of .955 for 6603 cases.

36. Since lagged Polity scores also predict voting rates, both elements of Participatory Democracy Granger cause the other. However, the effect in the reverse direction is less than half as strong. The analysis is available from the authors.

37. A similar conclusion follows from an unreported analysis of an extension of equation (7) beyond one year. With higher-order lags, participation attained greater significance and the predictive power of lagged polity declined. At 10 years, the two are about equally good predictors and, at 20 years, lagged Polity scores make no additional contribution to the prediction offered by participation rates.

38. The participation measure, VTS, is computed from Vanhanen's turnout data and Maddison's population estimate.

39. Past values of democracy predict 1950 and 1973 less well, regardless of the base year. Presumably this aberration reflects the emergence of the highly autocratic systems of Eastern Europe after World War II.

40. Because they also have the earliest base years, it may instead signify an era effect.

41. In analyses not presented, both PEPS1 and PEPS2 are also shown to have higher serial correlation than Polity.

42. Such cross-time inferences are both appropriate and necessary because democracy is not an idea well suited for discrete point estimates at precise instants. Its essence lies in linkages that are revealed only over time, especially that the preferences expressed in elections are reflected in subsequent policies. Nevertheless, statistical testing methods require that we make such simplifying assumptions.

43. We recognize that improvements in social welfare will ultimately depend on a combination of political participation, national wealth, state capacity, and many other factors not included in this analysis.

44. These three social indicators - life expectancy, adult literacy, and gross school enrollments - are also featured in the Millennium Development goals, and two of them enter the venerable Physical Quality of Life Index (PQLI) frequently used in previous basic needs studies. 
45. Gender equality can be assessed along several partially colinear dimensions, including labor force participation, literacy, and office holding (Marshall, 1985; Pampel and Tanaka, 1986; Miller, 1999). Following UNDP (1995), we focus on education, income, and life chances.

46. Most have focused almost exclusively on economic development as the independent variable (Jalan and Subbarao, 1994; Easterly, 1997; Filmer et al., 1998; Forsythe et al., 2000).

47. The GDI is first described in UNDP (1995). Its critics, who note that it mixes absolute levels of attainment and indicators of inequality, include Dijkstra (2002), Forsythe et al. (1998), Jalan and Subbarao (1994), Bardhan and Klasen (1999), and Dijkstra and Hammer (2000). Our data for 2003 are taken from the UNDP web site.

48. This may explain why other studies have found little evidence of a democracy effect (Williamson and Boehmer, 1997; Paxton, 1997; Dollar and Gatti, 1999; Brown, 2004).

49. These contrasts are even more dramatic, and the generality of the effects increased when the analysis was conducted with the turnout measure that codes the absence of IDEA data as indicative of zero participation.

50. We cannot discount the possibility that reciprocal causation is at work in either the Human Development or Gender Development regressions, but a full econometric specification of the complex dynamics involving growth, distribution, and elements of the political system are beyond the bounds of this article.

\section{References}

Adcock, Robert and David Collier. 2000. "Connecting Ideas with Facts: The Validity of Measurement." Annual Meeting of the American Political Science Association (Washington, DC, 2000).

Administration and Cost of Elections (ACE) Project. 2003. http://www.aceproject.org/

Aristotle. 1996. The Politics, Stephen Everson, ed. Cambridge: Cambridge University Press.

Bardhan, Kalpana and Stephan Klasen. 1999. "UNDP's Gender-Related Indices: a Critical Review." World Development 27: 985-1010.

Barro, Robert.1996. "Democracy and Growth.” Journal of Economic Growth 1: 1-27.

Bebbington, Anthony. 1999. "Capitals and Capabilities." World Development 27 (12): 2021-2044.

Bhagwati, Jagdish. 1992. "Democracy and Development.” Journal of Democracy 3(3): 37-44.

Blais, Andre and Agnieszka Dobrzynska. 1998. “Turnout in Electoral Democracies," European Journal of Political Research 33: 239-261.

Boix, Carles and Susan C. Stokes. 2003. "Endogenous Democratization.” World Politics 55 (July): 517-549.

Bollen, Kenneth A. 1980. "Issues in the Comparative Measurement of Political Democracy." American Sociological Review 45: 370-390

_. 1983. "World System Position, Dependency, and Democracy: The Cross-National Evidence." American Sociological Review 48: 468-479.

Bollen, Kenneth A. and Pamela Paxton. 2000. "Subjective Measures of Liberal Democracy." Comparative Political Studies 33(1): 58-86.

Brown, David S. 2004. "Democracy and Gender Inequality in Education: A Cross-National Examination.” British Journal of Political Science 34: 137-152.

Brunetti, A. 1997. "Political variables in Cross-Country Growth Analysis." Journal of Economic Surveys 11: 11163-190.

Burkhardt, Ross E. and Michael Lewis-Beck. 1994. "Comparative Democracy: The Economic Development Thesis." American Political Science Review 88: 903-910.

Chambers, Robert. 1997. Whose Reality Counts? London: Intermediate Technology Publications.

Dahl, Robert A. 1971. Polyarchy: Participation and Opposition. New Haven: Yale University Press.

Diamond, Larry, Linz, J. Juan, and Lipset, Seymour Martin, eds. 1988-9. Democracy in Developing Countries. 3 vols. Boulder, Colorado: Lynne Rienner.

Dijkstra, A. Geske. 2002. "Revisiting UNDP's GDI and GEM: Towards an Alternative.” Social Indicators Research 57: 301-338.

Dijkstra, A. Geske and Lucia Hammer. 2000. "Measuring Socio-Economic Gender Equality: toward an Alternative for UNDP's GDI.” Feminist Economics 6: 41-75. 
Dollar, David and Roberta Gotti. 1999. "Gender Inequality, Income, and Growth: Are Good Times Good for Women?" World Bank Research Report.

Easterly, William. 1997. "Life During Growth.” World Bank Research Report 428.

Eckstein, Harry and Gurr, Ted R. 1975. Patterns of Authority: A Structural Basis for Political Inquiry. New York: Wiley

Elkins, Zachary. 2000. "Gradations of Democracy? Empirical Tests of Alternative Conceptualizations." American Journal of Political Science 44(2) (April): 293-300.

Filmer, Deon, Elizabeth M. King, and Lant Pritchett. 1998. "Gender Disparity in South Asia: Comparisons between and within Countries." World Bank Working Paper 1867

Finkel, Steven E. 1985. "Reciprocal Effects of Participation and Political Efficacy: A Panel Analysis." American Journal of Political Science 29(4) (November): 891-913.

Forsythe, Nancy, Roberto Patricio Korzeniewicz, and Valerie Durrant (2000) "Gender Inequalities and Economic Growth: A Longitudinal Evaluation." Economic Development and Cultural Change 573-617.

Franklin, Mark N. 1996. "Electoral Participation.” Pp. 216-235 in Lawrence LeDuc, Ricard Niemi, and Pippa Norris, eds. Comparing Democracies: Elections and Voting in Global Perspective. Thousand Oaks, California: Sage Publications.

Freedom House. 2000. “Annual Survey of Freedom Country Scores, 1972-1973 to 1999-2000,” http:/ /freedomhouse.org/rationgs/index.htm.

_ 2002. "Freedom in the World 1999-2000." http://www.freedomhouse.org/ratings/index.htm

Freire, Pablo. 1998. Pedagogy of Freedom. Oxford: Rowman \& Littlefield

Gastil Raymond D. "The Comparative Survey of Freedom: Experiences and Suggestions." Freedom House.

Gleditsch, Kristian S. and Michael D. Ward. 1997. "Double Take: A Reexamination of Democracy and Autocracy in Modern Politics." Journal of Conflict Resolution 41(3) (June): 361-383.

Gough, Ian. 2000. Global Capital, Human Needs, and Social Policies. New York: St. Martin's Press.

Haas, Michael. 1974. International Conflict. New York: Bobbs-Merrill.

Hadenius, Axel and Jan Teorell. 2005. "Cultural and Economic Prerequisites of Democracy: Reassessing Recent Evidence.” Studies in Comparative International Development 39(4) (Winter): 87-106.

Hewitt, Christopher. 1977. "The Effect of Political Democracy and Social Democracy on Equality in Industrial States." American Sociological Review 42: 450-464.

Huber, Evelyn, Dietrich Rueschemeyer, and John Stephens. 1993. "The Impact of Economic Development on Democracy." Journal of Economic Perspectives 7(3) (Summer): 71-87.

Huntington, Samuel. 1987. Understanding Political Development. Boston: Little, Brown.

— 1991. The Third Wave: Democratization in the Late Twentieth Century. Norman: University of Oklahoma Press.

IDEA. 2003. International Institute for Democracy and Electoral Assistance http://www.idea.int/vt/ index.cfm

Jackman, Robert W. 1973. "On the Relation of Economic Development to Democratic Performance." American Journal of Political Science 17: 611-621

Jackman, Robert W. 1987. "Political Institutions and Voter Turnout in the Industrial Democracies." American Political Science Review 81(2) (June): 405-424.

Jaggers, Keith and Ted Robert Gurr. 1995. "Tracking Democracy's Third Wave with the Polity III Data." Journal of Peace Research 32: 469-482.

Jalan, Jyotsna and K. Subbarao. 1994. "Gender Disparity in Human Resource Development: Cross Country Patterns." Education and Social Policy Department, World Bank, ESP Discussion Paper Series 25. (April)

Key, V.O. 1949. Southern Politics in State and Nation. New York: Vintage Books.

Klasen, Stephan. 1999. Does Gender Inequality Reduce Growth and Development? Evidence from Cross-Country Regressions. Working Paper 7. Washington, DC: The World Bank

Lake, David A. and Matthew A. Baum. 2001. "The Invisible Hand of Democracy: Political Control and the Provision of Public Services." Comparative Political Studies 34(6) (August): 587-621.

Lijphart, Arend. 1997. "Unequal Participation: Democracy's Unresolved Dilemma." American Political Science Review 91(1) (March): 1-14.

Lindblom, Charles. 1977. Politics and Markets: The World's Political-Economic Systems. New York: Basic Books. 
Lipset, Seymour M. 1959. "Some Social Requisites of Democracy.” American Political Science Review 53: 69-105.

. 1994. "The Social Requisites of Democracy Revisited." American Sociological Review 59: $1-22$.

Lipset, Seymour Martin, Kyoung-Ryung Seong, and John Charles Torres. 1993. "A Comparative Analysis of the Social Requisites of Democracy.” International Social Science Journal 45(2) (May): 155-176.

Maddison, Angus. 2001. The World Economy: A Millennial Perspective. Paris: Development Centre of the Organisation for Economic Co-operation and Development (OECD).

Mahler, Vincent. 2002. "Exploring the Subnational Dimension of Income Inequality: An Analysis of the Relationship Between Inequality and Electoral Turnout in the Developed Countries." International Studies Quarterly 46: 117-142.

Mansfield, Edward D. and Rachel Bronson. 1997. "Alliances, Preferential Trading Arrangements, and International Trade.” American Political Science Review 91(1) (March): 94-107.

Mansfield, Edward D., Helen V. Milner, and B. Peter Rosendorff. 1998. "Why Democracies Cooperate More: Electoral Control and International Trade Agreements.” Paper presented to the annual meeting of the American Political Science Association, Boston.

Mansfield, Edward D., Helen V. Milner, and B. Peter Rosendorff. 2000. "Free to Trade: Democracies, Autocracies, and International Trade.” American Political Science Review 94(2) (June): 305321.

Maoz, Zeev and Bruce Russett. 1993. "Normative and Structural Causes of Democratic Peace, 19461986." American Political Science Review 87: 624-638.

Marshall, Monty G., Ted Robert Gurr, Christian Davenport, and Keith Jaggers. 2002. "Polity IV, 1800 1999: Comments on Munck and Verkuilen." Comparative Political Studies 35(1) (February): 40-45.

Marshall, Monty G. and Keith Jaggers. 2001. Polity IV Project: Political Regime Characteristics and Transitions, 1800-1999, Dataset Users Manual. http://www.bos.umd.edu/cidcm/polity/

Marshall, Susan E. 1985. "Development, Dependence, and Gender Inequality in the Third World." International Studies Quarterly 29: 217-240.

Mayhew, David R. 1974. Congress New Haven: Yale University Press.

Miller, Carol D. 1999. "How Did Economic Development and Trade Affect Women's Share of the Labor Force in the 1980s?" Journal of World-Systems Research 5(3) (Fall): 363-374.

Mitchell, Neil J. and James M. McCormick. 1988. "Economic and Political Explanations of Human Rights Violations.” World Politics 40.

McDonald, Michael P. and Samuel L. Popkin (2001) "The Myth of the Vanishing Voter," American Political Science Review 95(4) (December): 963-974.

Moon, Bruce E. 1991. The Political Economy of Basic Human Needs. Ithaca: Cornell University Press.

Moon, Bruce E. and William J. Dixon. 1985. "Politics, the State, and Basic Human Needs: A CrossNational Study." American Journal of Political Science 29: 661-694.

Munck, Gerardo L. and Jay Verkuilen. 2002a. "Conceptualizing and Measuring Democracy: Evaluating Alternative Indices.” Comparative Political Studies 35(1) (February): 3-34.

Munck, Gerardo L. and Jay Verkuilen. 2002b. "Generating Better Data: A Response to Discussants." Comparative Political Studies 35(1) (February): 52-57.

Neubauer, D. E. 1967. "Some Conditions of Democracy.” The American Political Science Review 61 (4): 1002-1009.

Nussbaum, Martha. 2000. Women and Human Development: The Capabilities Approach. Cambridge: Cambridge University Press.

O’Neal, John R. and Bruce M. Russett. 1997. "The Classical Liberals Were Right: Democracy, Interdependence, and Conflict, 1950-1985.” International Studies Quarterly 41 (June): 267-293.

Osmani, Siddiq and Amartya Sen. 2003. "The Hidden Penalties of Gender Inequality: Fetal Origins of Ill-Health.” Economics and Human Biology 1: 105-121

Palmer, R. and J. Colton. 1992. A History of the Modern World, New York: McGraw-Hill, Inc.

Pampel, Fred C. and Kazuko Tanaka. 1986. "Economic Development and Female Labor Force Participation: A Reconsideration.” Social Forces 64(3): 599-619. 
Parry, Moyser and Day. 1992. Political Participation and Democracy in Britain. Cambridge: Cambridge University Press.

Paxton, Pamela. 1997. "Women in National Legislatures: A Cross-National Analysis." Social Science Research 26: 442-464.

- (2000) “Women's Suffrage in the Measurement of Democracy: Problems of Operationalization." Studies in Comparative International Development 35 (3) (Fall): 92-111

Paxton, Pamela, Kenneth A. Bollen, Deborah M Lee, and HyoJoung Kim. (2003) "Research Forum: A Half-Century of Suffrage: New Data and a Comparative Analysis." Studies in Comparative International Development 38(1): 93.

Pérez-Liñán, Aníbal. 2002. "Neoinstitutional Accounts of Voter Turnout: Moving Beyond Industrial Democracies." Electoral Studies 20: 281-297.

Pieterse, Jan Nederveen. 2002. "Participatory Democratization Reconceived." Futures 33: 407-422.

Pintor, Rafael Lopez and Maria Gratschew. 2002. Voter Turnout since 1945: A Global Report Stockholm: International Institute for Democracy and Electoral Assistance.

Poe, Steven C. and C. Neal Tate. 1994. "Repression of Human Rights to Personal Integrity in the 1980s: A Global Analysis.” American Political Science Review 88: 853-72.

Powell, G. Bingham Jr. 1986. “American Voter Turnout in Comparative Perspective.” American Political Science Review 80(1) (March): 17-43.

Putnam, Robert D. 1993. Making Democracy Work: Civic Traditions in Modern Italy Princeton: Princeton University Press.

Przeworski, Adam and Fernando Limongi. 1997. "Modernization: Theories and Facts.” World Politics 49: 155-183.

Przeworski, Adam, Michael E. Alvarez, Jose Antonio Cheibub, and Fernando Limongi. 2000. Democracy and Development: Political Institutions and Well-Being in the World, 1950-1990. Cambridge: Cambridge University Press.

Rosenstone, Steven J. and John Mark Hansen. 1993. Mobilization, Participation, and Democracy in America. (New York: Macmillan)

Rostow, Walter W. 1971. The Stages of Economic Growth: A Non-communist Manifesto. 2 ed. Cambridge: Cambridge University Press.

Sartori, Giovanni. 1987. The Theory of Democracy Revisited. Chatham, NJ: Chatham House.

Schumpeter, Joseph A. 1950. Capitalism, Socialism, and Democracy. New York: Harper \& Row.

Scoones, Ian. 1998. "Sustainable Rural Livelihoods: A Framework for Analysis.” Working Paper 72. Brighton, UK: Institute for Development Studies.

Sen, Amartya. 1999. Development as Freedom. New York: Anchor Books.

Sirowy, Larry and Alex Inkeles. 1980. "The Effects of Democracy on Economic Growth and Inequality: A Review. Studies in Comparative International Development 25: 126-157.

Starr, Harvey. 1991. "Democratic Dominoes: Diffusion Approaches to the Spread of Democracy in the International System.” Journal of Conflict Resolution 35(2): 356-381. - 1999. "Democratic Dominoes Revisited: Democratic Diffusion, 1974-1996." Paper presented to the Annual Meetings of the International Studies Association, Washington, DC.

United Nations Development Program. 1995. Human Development Report 1995. New York: Oxford.

United Nations Development Program. 2000. Human Development Report 2000. (New York: Oxford University Press).

Vanhanen, Tatu. 1990. The Process of Democratization: A Comparative Study of 147 States, 1980-88. New York: Taylor and Francis.

_. 2000. "A New Dataset for Measuring Democracy, 1810-1998." Journal of Peace Research 37(2): 251-265.

Williamson, John B. and Ulrike Boehmer. 1997. "Female Life Expectancy, Gender Stratification, Health Status, and Level of Economic Development: A Cross-National Study of Less Developed Countries." Social Science Medicine 45(2): 305-317.

Young, Iris. 1999. Inclusion and Democracy. Oxford: Oxford University Press.

Zakaria, Fareed. 1997. "The Rise of Illiberal Democracy." Foreign Affairs 76(6) (Nov/Dec): 22-43. 